\title{
Architecture and controls of thick, intensely bioturbated, storm-influenced shallow-marine successions: An example from the Jurassic Neuquén Basin (Argentina)
}

\author{
E. Schwarz ${ }^{\mathrm{a},{ }^{*}}$, M. Poyatos-Moré ${ }^{\mathrm{b}}$, S. Boya ${ }^{\mathrm{c}}$, L. Gomis-Cartesio $^{\mathrm{d}}$, I. Midtkandal ${ }^{\mathrm{b}}$ \\ ${ }^{\text {a }}$ Centro de Investigaciones Geológicas, Universidad Nacional de La Plata-CONICET, Argentina \\ ${ }^{\mathrm{b}}$ Department of Geosciences, University of Oslo, Norway \\ ${ }^{\mathrm{c}}$ Departament de Geologia, Universitat Autònoma de Barcelona, Spain \\ ${ }^{\mathrm{d}}$ Equinor ASA, Research Centre, Bergen, Norway
}

\section{A R T I C L E I N F O}

\section{Keywords:}

Storm-surge flows

Biogenic destruction

Long-term aggradational stacking pattern

Bardas Blancas Formation

\begin{abstract}
A B S T R A C T
Thick ( $>100$ m-thick), highly bioturbated storm-influenced shallow-marine deposits are not frequent in the stratigraphic record, but they tend to be common in aggradational to retrogradational successions. Individual storm-event beds have typically low preservation potential in these successions, yet depositional settings are characterized on the basis of storms processes. Here we present a sedimentological study of a thick, bioturbated exhumed succession deposited during the early post-rift stage of the Neuquén Basin (Argentina) and compare its stratigraphic record with examples worldwide, in order to discuss the potential factors controlling the total overprint of storm-event beds during several million years. The Bardas Blancas Formation being 170-220 m thick in the study area is dominated by muddy sandstones and sandy mudstones, and it also includes subordinate proportions of clean sandstones and pure mudstones, collectively representing different environments of a storminfluenced shoreface-offshore system. The offshore transition and proximal offshore strata invariably comprise intensely bioturbated deposits, with only a few preserved HCS-sandstone beds. The unit shows for most of its thickness a long-term aggradational pattern spanning 7-10 Myr and is associated with low riverine influence.

By combining the observations and interpretations of the Bardas Blancas Formation with other subsurface and exhumed intensely bioturbated, shallow-marine successions, we dispute the general assumption that these are associated with low frequency or low magnitude of storms. Alternatively, we argue that the long-lived efficiency of benthic fauna on overprinting most if not all the storm-event beds that reached the offshore-transition sector, results from the combination of several factors: deposition in relatively confined marine depocentres, persistent low riverine influence, and long-term aggradational stacking pattern. As these conditions can develop in a variety of basin styles, such as rift, early post-rift, and foreland settings, the recognition of thick, bioturbated successions as the ones discussed here can be used to infer more realistic constrains for depositional models and better predict facies distribution in such storm-influenced systems.
\end{abstract}

\section{Introduction}

The deposition and preservation of individual storm-related event beds in shallow-marine settings have been reported and extensively discussed in the literature (Niedoroda et al., 1989; Wheatcroft, 1990; Snedden and Nummedal, 1991; MacEachern and Pemberton, 1992; among many others). Facies models for wave- and storm-dominated shoreline and shallow-marine systems are relatively well established (e.g., Walker and Plint, 1992; Reading and Collinson, 1996; Johnson and Baldwin, 1996; Clifton, 2006; Plint, 2010), and they are recently incorporating two-dimensional, quantitative studies for refining shoreline reconstructions (e.g., Isla et al., 2020a, 2020b). MacEachern and Pemberton (1992) characterized three types of shorefaces based on the intensity and frequency of storms: intense, moderate, and weak (lowenergy) shorefaces. It is typically assumed that a thoroughly bioturbated succession with little or not preserved storm-event beds within a storm-

\footnotetext{
* Corresponding author.

E-mail addresses: eschwarz@cig.museo.unlp.edu.ar (E. Schwarz), miquel.poyatos-more@geo.uio.no (M. Poyatos-Moré), LUZG@equinor.com (L. Gomis-Cartesio), ivar.midtkandal@geo.uio.no (I. Midtkandal).
} 
influenced shoreface-offshore system would represent weakly stormaffected shorefaces dominated by fair-weather deposits (MacEachern and Pemberton, 1992; MacEachern et al., 1999; Pemberton et al., 2012).

More than $100 \mathrm{~m}$ thick successions of storm-influenced, shallowmarine deposits characterized by highly bioturbated strata are not frequent in the stratigraphic record. However, they tend to be unusually common in rift to early post-rift stages of the North Sea Central Graben (Fraser et al., 2003; Gowland, 1996; Howell and Flint, 1996; Baniak et al., 2014), in rift stages of the North Sea Viking Graben (Ravnås et al., 1997; Løseth et al., 2009), and in early post-rift stages of the South American Neuquén Basin (Bardas Blancas Formation, Veiga et al., 2013). Other unusual examples of highly bioturbated, storm-influenced successions include the Bridport Sand Formation in the extensional Wessex Basin (Morris et al., 2006) and the Late Cretaceous Emery Sandstone Member of the Mancos Shale in the Western Interior foreland basin (Edwards et al., 2005). However, a thorough analysis of all these examples to test if they can be simply placed in the low-energy shoreface end-member of the MacEachern and Pemberton (1992) spectrum, or if there are other controlling factors that contribute to produce thick bioturbated storm-influenced successions, has not yet been attempted.

In this study, we present a detailed sedimentological study of a thick, highly bioturbated succession exposed in the northern Neuquén Basin (Lower-Middle Jurassic, Bardas Blancas Formation) with the following objectives: a) to describe and analyse an intensely bioturbated, storminfluenced shallow-marine succession, b) to compare the stratigraphic record of the Bardas Blancas Formation with thick, highly bioturbated units from other basins, c) to discuss the combination of several depositional controls that contribute to the complete destruction of original sedimentary structures and storm-event beds during several million years.

\section{Geologic and stratigraphic setting}

The Neuquén Basin is located on the eastern side of the Andes in west-central Argentina, between latitudes $32^{\circ}$ and $40^{\circ}$ South, covering an area of over $150,000 \mathrm{~km}^{2}$ (Fig. 1A). It comprises a nearly continuous stratigraphic record of up to $6000 \mathrm{~m}$ thick strata from the Upper Triassic to Lower Cenozoic, and it is one of the most important petroleum provinces of South America (e.g. Legarreta and Uliana, 1991). The sedimentary record of the Neuquén Basin includes continental and marine siliciclastics, carbonates, and evaporites, deposited under a variety of basin settings (Legarreta and Uliana, 1991; Howell et al., 2005).

During the Late Triassic to Early Jurassic, the western border of Gondwana was characterized by large transcurrent fault systems. This led to extensional tectonics within the Neuquén Basin and the formation of a series of narrow, relatively isolated depocentres (Franzese and Spalletti, 2001), which were filled mostly with volcanic and continental successions (Franzese et al., 2006; D'Elia et al., 2015). Due to continuous subduction at the proto-Pacific margin of Gondwana, a transition from syn- to post-rift conditions occurred in the late Early Jurassic (Vergani et al., 1995), marked by the first marine incursion into the basin (Gulisano, 1981; Veiga et al., 2013). The Neuquén Basin became a depocentre with regional slow subsidence in a back-arc position during the sag/post-rift phase that lasted to the end of the Early Cretaceous (Legarreta and Uliana, 1991). In the earliest stage of the post-rift phase, sediment gravity flows and mass movements were particularly common in marine settings, and this has been related to steep gradients (e.g., Legarreta and Uliana, 1996; Burgess et al., 2000; Privat et al., 2018). In this context, low-amplitude eustatic fluctuations, as well as short-lived events of tectonic inversion, probably had a strong influence during the entire post-rift evolution (Legarreta and Uliana, 1991; Howell et al., 2005), but inherited topography and differential compaction had been invoked as potential local factors in the development of early post-rift

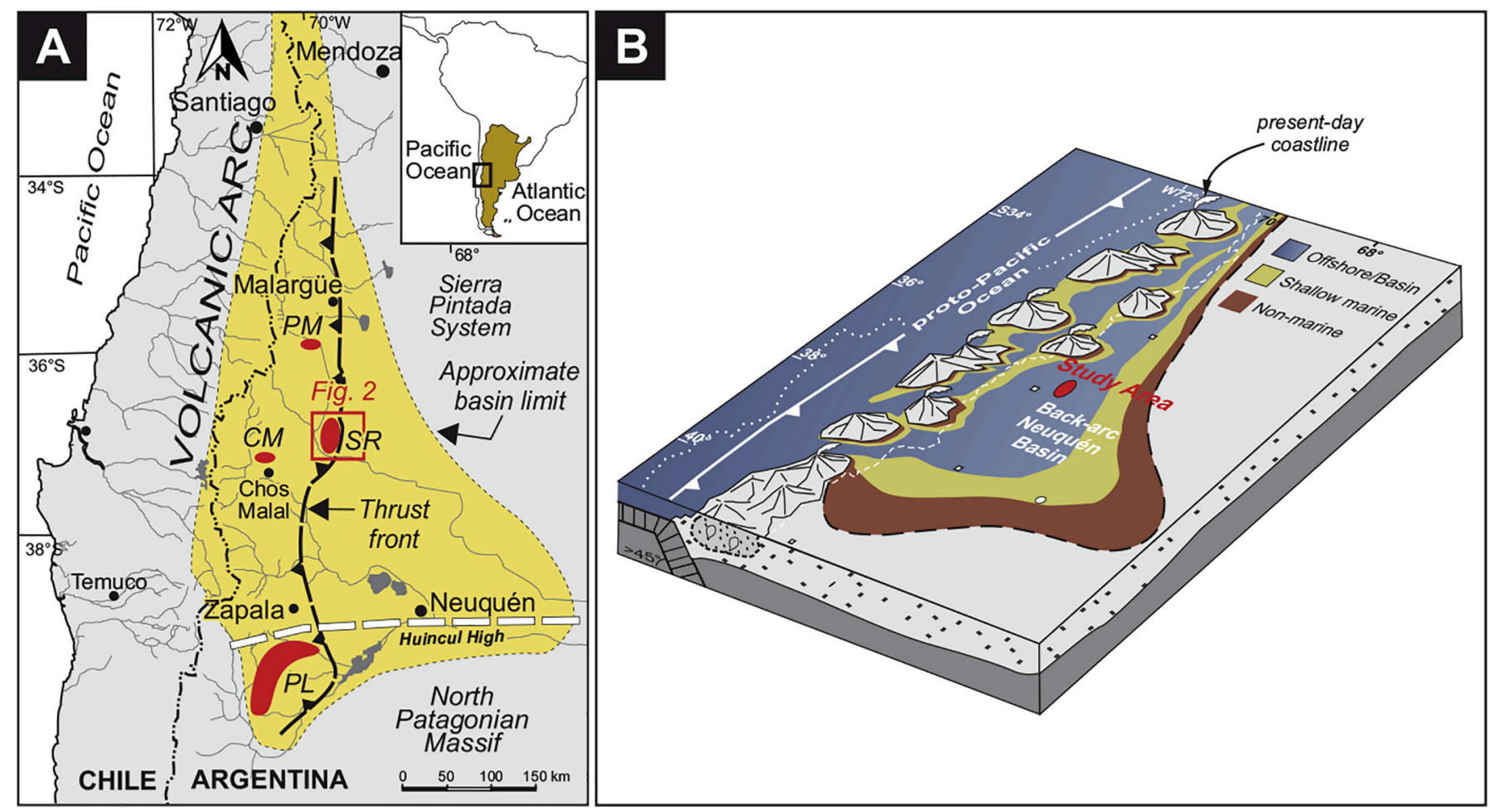

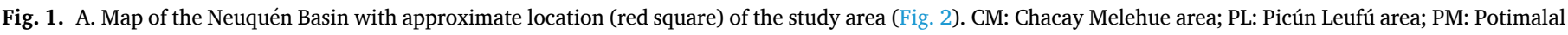

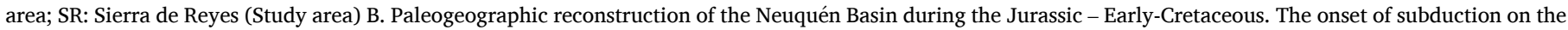

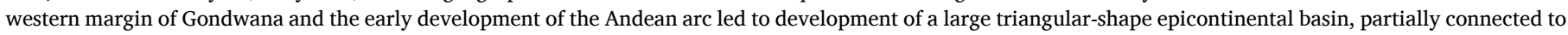

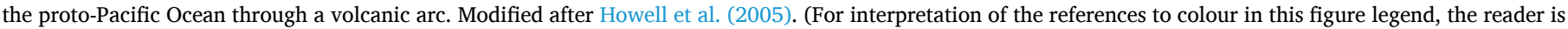
referred to the web version of this article.) 
strata, particularly in the central Neuquén Basin (Cristallini et al., 2009; Veiga et al., 2013).

The Cuyo Group represents the early post-rift sedimentation all across the Neuquén Basin (Figs. 1,2). It commonly overlies the Precuyano volcanic and volcaniclastic succession deposited during the synrift stage (Gulisano et al., 1984), but it can also rest directly upon Paleozoic volcanic or plutonic rocks (e.g., Choiyoi Group, Fig. 2). The Cuyo Group spans from Lower to Middle Jurassic and comprises deepmarine to continental deposits in different proportion depending on the position in the basin, with a general east (proximal)-west (distal) depositional trend (Gulisano et al., 1984; Arregui et al., 2011; Brinkworth et al., 2018). In the west-central sector of the Neuquén Basin (Fig. 1), the succession represents continuing deep-water sedimentation, strongly influenced by sediment gravity flows and mass-transport processes (Burgess et al., 2000; Hodgson et al., 2018), and is collectively known as the Los Molles Formation (Gulisano and Gutiérrez Pleimling, 1994). In the study area, in the east-central sector of the basin (Fig. 1A), early post-rift sediments deposited mostly in shallow-marine settings (Veiga et al., 2013), and accumulation started in the Late Toarcian-Aalenian (Riccardi, 2008; Spalletti et al., 2012). Lithostratigraphically, in this region the Cuyo Group includes the Bardas Blancas, Los Molles and Lajas formations (Gulisano and Gutiérrez Pleimling, 1994; Spalletti et al., 2012; Veiga et al., 2013) (Fig. 2). The Cuyo Group is truncated by the Intra-Callovian unconformity and is overlain by the Lotena Group (Gulisano et al., 1984) (Fig. 2).

The Bardas Blancas Formation, the focus of this contribution, is broadly defined as a Lower-Middle Jurassic marine succession (Gulisano and Gutiérrez Pleimling, 1994). It crops out in the Malargüe anticline, particularly in the Potimalal area (Fig. 1A), where it has been described as mostly composed of shoreface to offshore sandstones and mudstones, with subordinated deltaic and terrestrial deposits (Bressan et al., 2013). This unit has been also the focus of investigation in the study area (Sierra de Reyes anticline, Fig. 1A), as part of larger-scale studies including the Cuyo and Lotena Groups (Veiga et al., 2011; Spalletti et al., 2012; Veiga et al., 2013).

\section{Study area and previous work}

Veiga et al. (2013) provided a detailed architectural and sequence stratigraphic analysis of the Bardas Blancas Formation in the Sierra de Reyes study area, integrating outcrop and subsurface information from a $3000 \mathrm{~km}^{2}$ large area. They included two outcrop sections in the western and eastern sectors of the Sierra de Reyes anticline and several wells in the eastern subsurface region (Fig. 2). That study provides a framework in which to place the detailed sedimentological and ichnological analysis of the western outcrops of the Bardas Blancas Formation in the Sierra de Reyes anticline (Fig. 3A).

The Sierra de Reyes anticline is located in the southernmost sector of the Malarguie fold and thrust belt, which is the product of tectonic inversion during Late Cretaceous-Neogene times (Giambiagi et al., 2009). The inversion in this region is related to reactivation of Mesozoic normal faults and new reverse structures that transferred shortening to the east (Giambiagi et al., 2009; Sagripanti et al., 2014). The study area in the western flank of the Sierra de Reyes anticline is about 5 by $1.5 \mathrm{~km}$, and the strata are mostly dipping $20-30^{\circ}$ to the east. The Bardas Blancas Formation is exposed through a series of west-east gullies in which the main sedimentary sections were measured (Fig. 3B). A few reverse faults affect the strata but for the most part the outcrop is laterally continuous

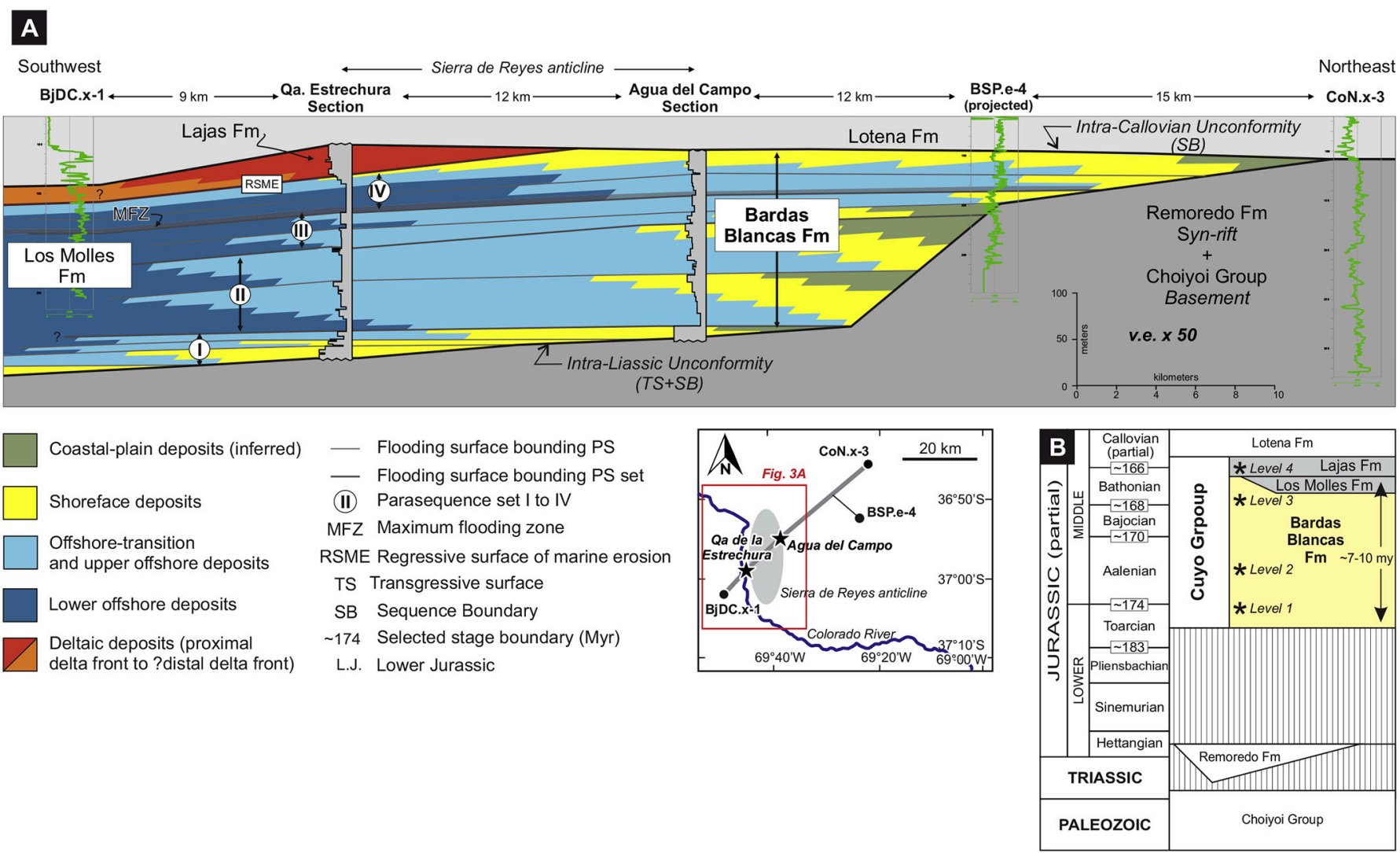

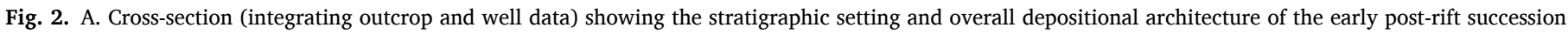

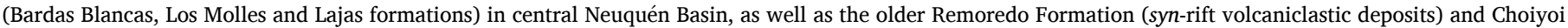

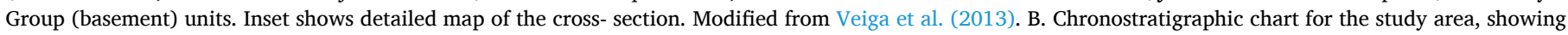

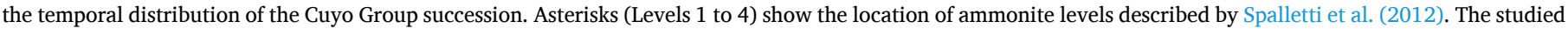
Bardas Blancas Formation (Toarcian-Bathonian) would represent a time interval ranging from 7 Myr to 10 Myr. 

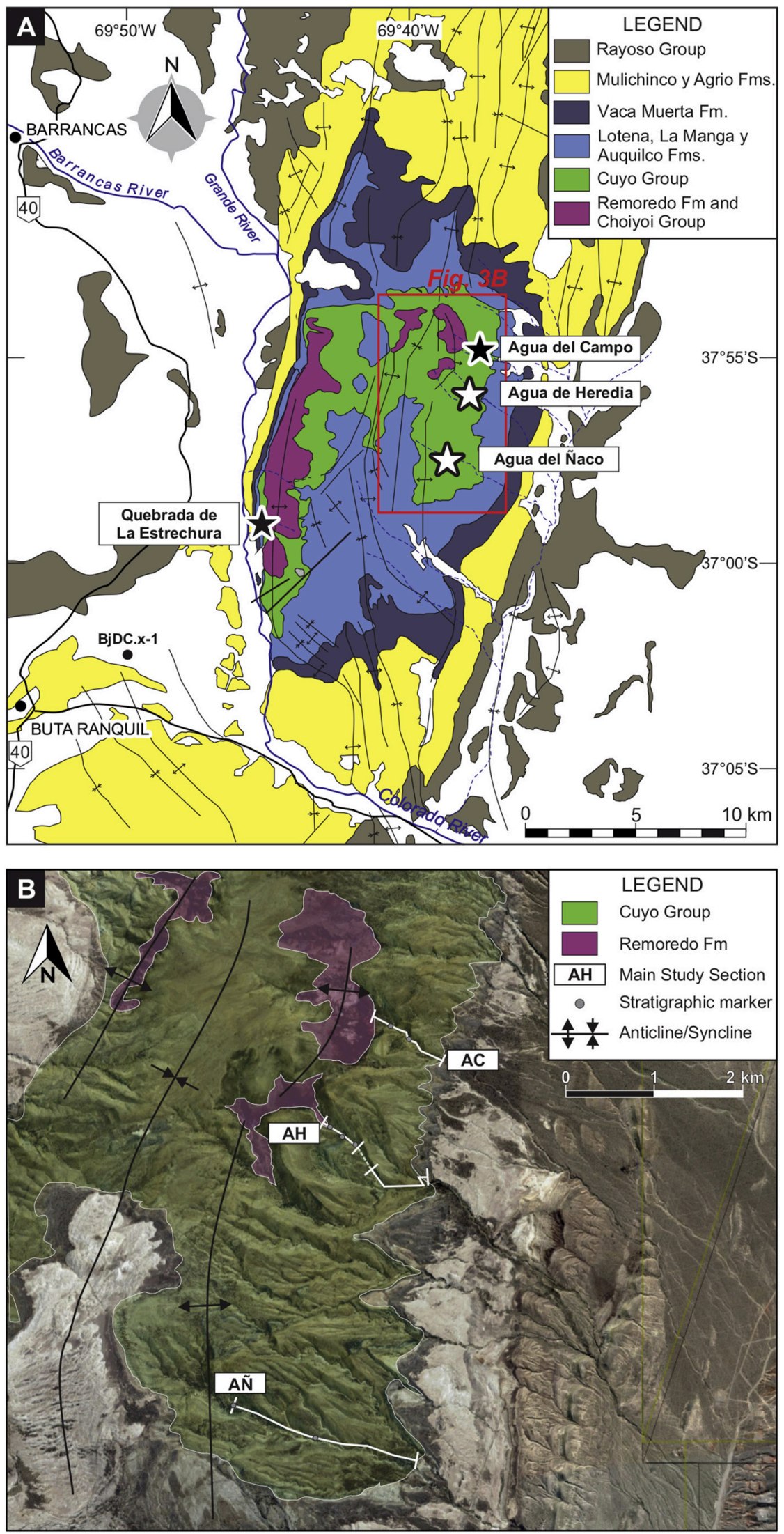

Fig. 3. A. Geologic map of the Sierra de Reyes region, showing the different locations studied by Veiga et al. (2013) (black stars) and this study (white stars). B. Satellite image of the study area, in the eastern flank of the Sierra de Reyes anticline, showing the location of the sections studied in the Cuyo Group. 
Table 1

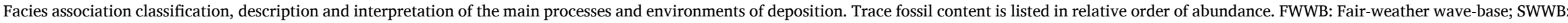
Storm-weather wave-base.

\begin{tabular}{|c|c|c|c|c|c|c|c|c|c|c|}
\hline Code & Texture & Structures & Thickness & Fossil content & Bioturbation & Trace fossils & Other & Presence & Interpretation & Environment \\
\hline FA1 & $\begin{array}{l}\text { Normally- to } \\
\text { inversely-graded } \\
\text { pebbly to medium- } \\
\text { grained } \\
\text { sandstones. }\end{array}$ & $\begin{array}{l}\text { Plane bed, planar } \\
\text { or trough cross- } \\
\text { stratification } \\
\text { (sets }<0.3 \mathrm{~m} \\
\text { thick), oriented } \\
\text { to W-SW. }\end{array}$ & $\begin{array}{l}0.3-1.5 \mathrm{~m} \\
\text { thick beds. }\end{array}$ & $\begin{array}{l}\text { Sand-size bioclasts } \\
\text { common, high degree of } \\
\text { fragmentation. Mostly } \\
\text { from bivalves, but } \\
\text { ammonite and } \\
\text { belemnite fragments } \\
\text { also present. }\end{array}$ & $\begin{array}{l}\text { Absent to } \\
\text { moderate } \\
\text { (BI 0-3). }\end{array}$ & $\begin{array}{l}\text { Skolithos suite: } \\
\text { Palaeophycus, } \\
\text { Ophiomorpha, } \\
\text { Arenicolites. }\end{array}$ & $\begin{array}{l}\text { Thin (up to } 40 \mathrm{~cm} \text {-thick) } \\
\text { extraformational } \\
\text { conglomerate layers with } \\
\text { quartz and volcanic lithic } \\
\text { pebbles (up to } 5 \mathrm{~cm} \text {-long) } \\
\text { with mudstone rip-up } \\
\text { clasts, and chaotic to } \\
\text { organized fabric. Rare } \\
\text { detrital glauconitic grains. } \\
\text { Tree trunks, micaceous and } \\
\text { organic debris preserved in } \\
\text { bedding planes. Crude } \\
\text { coarsening-upward } \\
\text { successions }\end{array}$ & $\begin{array}{l}\text { Only observed at } \\
\text { the base of Bardas } \\
\text { Blancas Fm. }\end{array}$ & $\begin{array}{l}\text { High-energy nearshore } \\
\text { setting, influenced by } \\
\text { terrestrial input of river- } \\
\text { related hyperpycnal } \\
\text { flows, and partly } \\
\text { reworked by subordinate } \\
\text { wave coastal processes. }\end{array}$ & Delta front \\
\hline FA2 & $\begin{array}{l}\text { Amalgamated fine- } \\
\text { to medium- } \\
\text { grained sandstones }\end{array}$ & $\begin{array}{l}\text { Structureless or } \\
\text { trough cross- } \\
\text { stratification } \\
\text { (sets }<0.5 \mathrm{~m} \\
\text { thick). }\end{array}$ & $\begin{array}{l}0.5-1.8 \mathrm{~m} \\
\text { thick beds. }\end{array}$ & $\begin{array}{l}\text { Occasional lenses of } \\
\text { shells with oriented } \\
\text { bioclasts at bed bases. }\end{array}$ & $\begin{array}{l}\text { Absent to low } \\
\text { (BI 0-2). }\end{array}$ & $\begin{array}{l}\text { Where observed, } \\
\text { Skolithos suite: } \\
\text { Ophiomorpha. }\end{array}$ & $\begin{array}{l}\text { Very well-sorted, "clean" } \\
\text { sandstones. Locally } \\
\text { preserved coarser grained, } \\
\text { bioclast-rich accumulations } \\
\text { at the top (transgressive } \\
\text { lags). }\end{array}$ & $\begin{array}{l}\text { Uncommon, only } \\
\text { observed towards } \\
\text { upper part of } \\
\text { some } \\
\text { parasequences. }\end{array}$ & $\begin{array}{l}\text { High-energy nearshore } \\
\text { setting, intensely } \\
\text { reworked by dominant } \\
\text { longshore currents. }\end{array}$ & $\begin{array}{l}\text { Upper } \\
\text { Shoreface }\end{array}$ \\
\hline FA3 & $\begin{array}{l}\text { Amalgamated to } \\
\text { tabular very fine- } \\
\text { to fine-grained } \\
\text { sandstones. }\end{array}$ & $\begin{array}{l}\text { HCS with } \\
\text { subordinate SCS } \\
\text { and plane bed. } \\
\text { Symmetrical } \\
\text { ripple tops } \\
\text { uncommon. }\end{array}$ & $\begin{array}{l}0.15-0.80 \mathrm{~m} \\
\text { thick beds. } \\
\text { Few m-thick } \\
\text { bedsets. }\end{array}$ & $\begin{array}{l}\text { Lenses of shells with } \\
\text { common bioclasts } \\
\text { oriented parallel to bed } \\
\text { bases. }\end{array}$ & $\begin{array}{l}\text { Low-moderate } \\
\text { to high (BI } \\
2-5 \text { ). }\end{array}$ & $\begin{array}{l}\text { Skolithos suite: } \\
\text { Arenicolites, } \\
\text { Skolithos, } \\
\text { Palaeophycus, } \\
\text { Ophiomorpha, }\end{array}$ & $\begin{array}{l}\text { Parting lineation, } \\
\text { micaceous and organic } \\
\text { (plant) debris common. } \\
\text { Occasional nodular } \\
\text { carbonate horizons, } \\
\text { associated with large } \\
\text { bioclast accumulations. }\end{array}$ & $\begin{array}{l}\text { Common in } \\
\text { studied sections, } \\
\text { mainly towards } \\
\text { upper part of } \\
\text { parasequences. }\end{array}$ & $\begin{array}{l}\text { Moderate to high energy } \\
\text { in marine environment, } \\
\text { above FWWB. Common } \\
\text { deposits of purely } \\
\text { oscillatory and/or } \\
\text { combined flows during } \\
\text { storms. Amalgamation } \\
\text { suggests erosion of fair- } \\
\text { weather sediments. }\end{array}$ & $\begin{array}{l}\text { Lower } \\
\text { shoreface }\end{array}$ \\
\hline FA4 & $\begin{array}{l}\text { Tabular very fine- } \\
\text { grained sandstones } \\
\text { and muddy } \\
\text { sandstones ( }<30 \% \\
\text { of mud), with } \\
\text { subordinate sandy } \\
\text { mudstones. }\end{array}$ & $\begin{array}{l}\text { Typically massive } \\
\text { due to very } \\
\text { intense } \\
\text { bioturbation. } \\
\text { Occasional HCS } \\
\text { or faint ripple } \\
\text { cross-lamination. }\end{array}$ & $\begin{array}{l}\text { Tabular beds } \\
\text { from } \\
0.10-0.40 \mathrm{~m} \\
\text { thick. Up to } \\
1.50 \mathrm{~m} \text { thick. } \\
\text { Several m- } \\
\text { thick bedsets. }\end{array}$ & $\begin{array}{l}\text { Bioclasts of infaunal and } \\
\text { semi-infaunal bivalves } \\
\text { common. Low to } \\
\text { moderate degree of } \\
\text { fragmentation, } \\
\text { articulated specimens } \\
\text { common, occasionally } \\
\text { preserved in life } \\
\text { position. Belemnite and } \\
\text { ammonite remains less } \\
\text { common. }\end{array}$ & $\begin{array}{l}\text { Mostly high } \\
\text { (BI 5-6), } \\
\text { occasionally } \\
\text { moderate (BI } \\
\text { 4). }\end{array}$ & $\begin{array}{l}\text { Cruziana suite: } \\
\text { Teichichnus, } \\
\text { Asterosoma, Rosselia, } \\
\text { Chondrites, Planolites, } \\
\text { Thalassinoides, } \\
\text { Rhizocorallium, } \\
\text { Palaeophycus, } \\
\text { Phycosiphon, } \\
\text { Zoophycos. }\end{array}$ & $\begin{array}{l}\text { Occasional preservation of } \\
\text { sandstone beds }(0.2-1.0 \mathrm{~m} \\
\text { thick), traceable for } 100 \text { 's } \\
\text { of } \mathrm{m} \text {. They are fine- to very } \\
\text { fine-grained, with HCS or } \\
\text { less commonly massive } \\
\text { grading upwards to planar- } \\
\text { laminated. Shells can be } \\
\text { concentrated at their bases. } \\
\text { Bioturbation (lam-scram) } \\
\text { increases from top } \\
\text { downwards. }\end{array}$ & $\begin{array}{l}\text { Broadly } \\
\text { distributed in } \\
\text { studied sections. }\end{array}$ & $\begin{array}{l}\text { Moderate to low energy } \\
\text { in marine environment, } \\
\text { below FWWB. Lower } \\
\text { proportion (or } \\
\text { preservation) of storm } \\
\text { deposits than lower } \\
\text { shoreface deposits. }\end{array}$ & $\begin{array}{l}\text { Offshore } \\
\text { transition }\end{array}$ \\
\hline FA5 & $\begin{array}{l}\text { Sandy mudstones } \\
\text { (50-70\% of mud) } \\
\text { and silty } \\
\text { mudstones, with } \\
\text { subordinate } \\
\text { mudstones and } \\
\text { muddy sandstones. }\end{array}$ & $\begin{array}{l}\text { Diffuse grain-size } \\
\text { changes, bedding } \\
\text { contacts are } \\
\text { diffuse, but } \\
\text { roughly parallel. }\end{array}$ & $\begin{array}{l}\text { Tabular beds } \\
\text { from } \\
0.20-0.80 \mathrm{~m} \\
\text { thick. }\end{array}$ & $\begin{array}{l}\text { Fragments of ammonites } \\
\text { and belemnites } \\
\text { frequent, benthic } \\
\text { macrofossils are } \\
\text { uncommon (mostly } \\
\text { oysters). }\end{array}$ & $\begin{array}{l}\text { Mostly high } \\
\text { (BI 5-6), } \\
\text { occasionally } \\
\text { moderate (BI } \\
\text { 4). }\end{array}$ & $\begin{array}{l}\text { Distal Cruziana suite: } \\
\text { Chondrites, } \\
\text { Phycosiphon, } \\
\text { Planolites, } \\
\text { Teichichnus, } \\
\text { Helminthopsis, } \\
\text { Thalassinoides, } \\
\text { Rhizocorallium, } \\
\text { diminute Skolithos, } \\
\text { Zoophycos. }\end{array}$ & $\begin{array}{l}\text { Discrete sandstone beds } \\
\text { less common than in FA4. } \\
\text { They show plane bed and } \\
\text { bioturbation decreasing } \\
\text { from top to bottom. }\end{array}$ & $\begin{array}{l}\text { Broadly } \\
\text { distributed in } \\
\text { studied sections. }\end{array}$ & $\begin{array}{l}\text { Low-energy conditions, } \\
\text { with cohesive substrates } \\
\text { and persistent oxic } \\
\text { conditions. Relatively } \\
\text { distal depositional } \\
\text { setting, around SWWB. }\end{array}$ & $\begin{array}{l}\text { Proximal } \\
\text { offshore }\end{array}$ \\
\hline FA6 & $\begin{array}{l}\text { Gray mudstones } \\
\text { and/or black } \\
\text { shales. }\end{array}$ & $\begin{array}{l}\text { Massive to } \\
\text { crudely } \\
\text { laminated. }\end{array}$ & $\begin{array}{l}\text { From } \mathrm{cm} \text { - to } \\
\text { several } \mathrm{m} \text { - }\end{array}$ & Foraminifera common. & $\begin{array}{l}\text { Absent to } \\
\text { moderate (BI } \\
0-3 \text { ). }\end{array}$ & $\begin{array}{l}\text { Zoophycos suite: } \\
\text { Zoophycos, } \\
\text { Phycosiphon, }\end{array}$ & $\begin{array}{l}\text { Occasional diagenetic } \\
\text { nodule-rich horizons. In } \\
\text { lower section, thin (up to }\end{array}$ & $\begin{array}{l}\text { Relatively } \\
\text { uncommon, } \\
\text { mainly observed }\end{array}$ & $\begin{array}{l}\text { Suspension settling in } \\
\text { very low-energy } \\
\text { conditions and devoid of }\end{array}$ & $\begin{array}{l}\text { Distal } \\
\text { offshore }\end{array}$ \\
\hline
\end{tabular}


Table 1 (continued)

Code Texture

Structures

Thickness

Fossil content

Bioturbation

Trace fossils

Other

Chondrites, Scolicia

$40 \mathrm{~cm}$-thick)

extraformational

Environment

packages.

conglomerate layers, with

mudstone rip-up clasts (up

to $10 \mathrm{~cm}$ ), chaotically

distributed in sandstone

beds or forming organized

intraformational

conglomerates. In upper

coherent black shales.

typically platy, with

absence of trace fossils and

scarce fragments of small,

scarce fragments of small,
thin-shelled bivalves. Cm-

thick tuffaceous layers

Presence

terpretation

of unit.

SWWB. Occasional

gravity-flow deposits in

the lower section.

Dysoxic to anoxic

conditions with organic-

rich substrates in the

transition to Los Molles

Fm. 

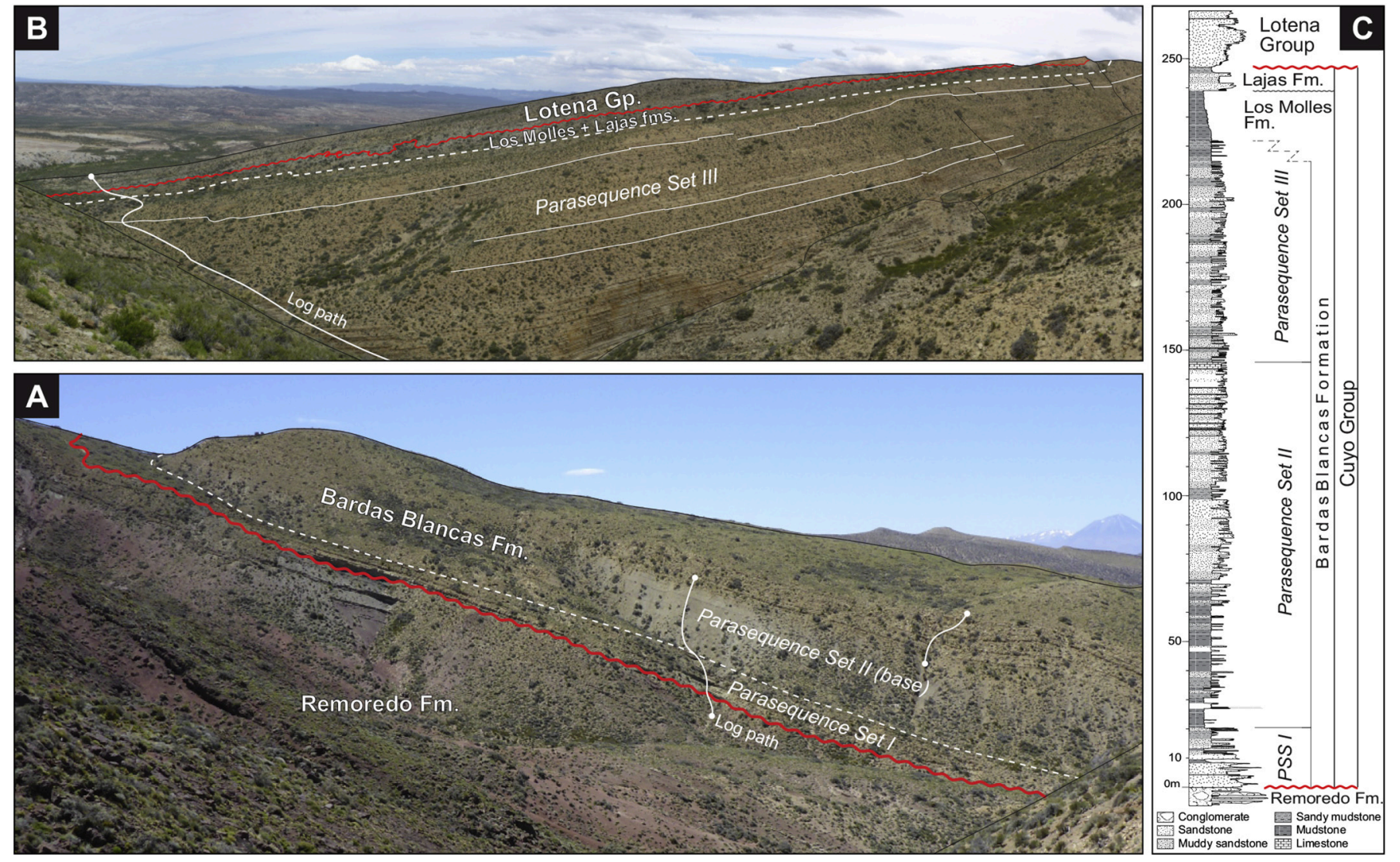

Fig. 4. Field panoramas of Agua del Campo (A) and Agua de Heredia (B), showing the location of main stratigraphic units, and their bounding surfaces. C. Simplified stratigraphic section showing the overall aggradational-to-retrogradational stacking of the Bardas Blancas Formation, and its vertical relationships with the underlying and overlying lithostratigraphic units. Parasequence sets (PSS's) after Veiga et al. (2013).

and allows reconstruction by means of key stratigraphic markers.

The Bardas Blancas Formation is dominated by muddy sandstones and sandy mudstones, and it also includes subordinate proportions of coarser deposits up to pebbly sandstones and pure mudstones. The unit is $170-220 \mathrm{~m}$ thick and it unconformably overlies the syn-rift volcaniclastic deposits of the Remoredo Formation across all the area (Figs. 3B, 4A). In the southern sector of the study area (Agua del Naco and Agua de Heredia sections, Fig. 3), the Bardas Blancas Formation rapidly grades into a muddy, organic-rich unit defined as part of Los Molles Formation (Gulisano and Gutiérrez Pleimling, 1994; Spalletti et al., 2012) (Fig. 4B, C). The thickness of the Los Molles reaches $20 \mathrm{~m}$ in the Agua del Naco section, and it thins and pinches out to the north. In the Agua del Campo section, the Bardas Blancas strata are sharply overlain by bioclastic and pebbly sandstones of the La Estrechura Member of the Lotena Formation (Veiga et al., 2011; Veiga et al., 2013). Biostratigraphic data based on ammonites of the study succession indicates that the Bardas Blancas Formation in the study area spans from the Late Toarcian to the Early Bathonian (Spalletti et al., 2012) (Fig. 2). According to present chronostratigraphic ages this time span represents no less than $7 \mathrm{Myr}$ and as much as 10 Myr (Cohen et al., 2013). Further to the west of the study area, time-equivalent deposits of the Bardas Blancas Formation are dominantly composed of mudstone strata of the Los Molles Formation, but they occur mostly in the subsurface (e.g., well BjDC.x-1 in Fig. 2).

The sequence architecture of the Cuyo Group in this region was investigated by Veiga et al. (2013). Integrating outcrop and subsurface data they identified four parasequence (PS) sets within the study interval (Figs. 2, 4), individually representing alternating conditions from retrogradational (PS Sets I and III) to aggradational (PS Set II), to progradational (PS Set IV) stacking patterns (Fig. 2). Collectively, the lower three parasequence sets were interpreted as representing long-term transgressive conditions during the early post-rift stage of the basin, where sustained accommodation was probably provided by a combination of thermal subsidence, differential compaction of syn-rift deposits and eustatic rise (Veiga et al., 2013). The observed changes in the stacking patterns were attributed to the effect of inherited topography from the underfilled syn-rift half-grabens, as sedimentation areas were expanding during progressive flooding and sediments were depositing in partially filled half-graben-segments with different gradients.

For the present study, the sedimentology and stratigraphy of the Bardas Blancas Formation and its transition to Los Molles Formation in the eastern sector of the Sierra de Reyes anticline was recorded by detailed logging of two main sections, namely the Agua de Heredia section ( $\left.36^{\circ} 55^{\prime} 22.82^{\prime \prime} \mathrm{S}, 69^{\circ} 39^{\prime} 53.77^{\prime \prime} \mathrm{W}\right)$, and the Agua del Naco section (36 $57^{\prime} 9.07^{\prime \prime}$ 'S, 69 40'42.80”W) (Figs. 3B, 4), and complemented with information extracted from the Agua del Campo section of Veiga et al. (2013) (36 54 $45.48 ”$ 'S, 69 $\left.39^{\prime} 29.94^{\prime \prime W}\right)$. Sedimentological data were recorded in each section (texture, sedimentary structures, palaeocurrents), along with ichnologic, macrofaunal and taphonomic information. Bioturbation intensity was characterized using the Bioturbation Index (BI 0-6, Taylor and Goldring, 1993). Sand-silt-mud content in bioturbated facies was visually estimated by using X10 lenses.

\section{Facies associations and depositional model}

The facies and facies associations of the Bardas Blancas Formation and its transition to Los Molles Formation are presented in Table 1. Six facies associations (FA) have been defined for the study interval including: FA1 - Delta front, FA2 - Upper shoreface, FA3 - Lower shoreface, FA4 - Offshore transition, FA5 - Proximal offshore, and FA6 Distal offshore. The definition and interpretation of these facies 
associations is broadly in agreement with the proposed by Veiga et al. (2013). Hereby we present a short description of facies associations and their interpretation and subsequently we describe the inferred depositional model.

\subsection{Delta front (FA1)}

FA1 occurs only at the base of the unit and is dominated by pebbly sandstones with planar cross-stratification or horizontal lamination, interbedded with subordinate conglomerates with quartz and volcanic pebbles (up to $5 \mathrm{~cm}$ in size), mudstone rip-up clasts and bioclasts in a chaotic to organized fabric (Table 1, Fig. 5A). Poorly defined coarseningupward successions are observed locally. This association is interpreted to represent a high-energy nearshore setting, heavily influenced by coarse terrestrial input of river-related hyperpycnal flows, and partly reworked by subordinate coastal- wave processes (Veiga et al., 2013).

\subsection{Upper shoreface (FA2)}

FA2 is composed of amalgamated fine- to medium-grained sandstones mostly with trough cross-stratification and occasional lenses of highly fragmented bioclasts (Fig. 5B). Bioturbational structures are absent to low with sparse Ophiomorpha (Table 1). This association is thought to reflect a wave-dominated, upper-shoreface setting, intensely affected by longshore currents (Walker and Plint, 1992; Clifton, 2006; Isla et al., 2020a).
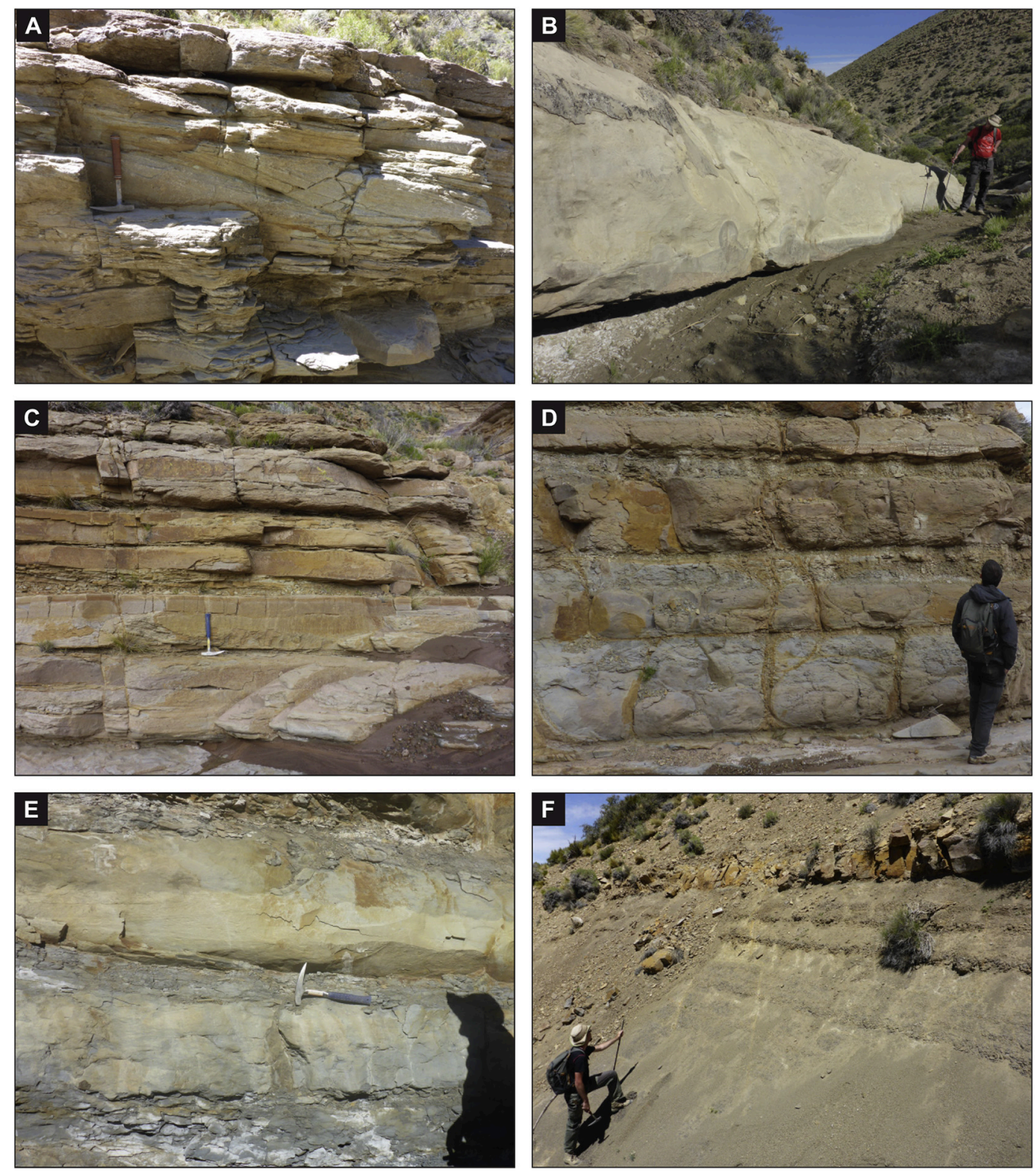

Fig. 5. Outcrop examples of the different facies associations defined in this study. A. Cross-bedded, organic-rich and poorly-sorted pebbly to medium-grained sandstones (FA1 - Delta Front). Parasequence Set I, Agua de Heredia. B. Amalgamated, trough cross-bedded, well-sorted fine-grained sandstones (FA2 - Upper shoreface). Parasequence Set I, Agua de Heredia. C. Tabular to slightly undulate, medium-bedded fine-grained sandstones, with hummocky cross-stratification (HCS) (FA3 - Lower shoreface). Parasequence Set II, Agua del Campo. D. Moderate to highly bioturbated sandstones and muddy sandstones, with local preservation of HCS (FA4 - Offshore transition). Parasequence Set II, Agua del Campo. E. Highly bioturbated sandy and silty mudstones, with subordinate muddy sandstones (FA5 Proximal offshore). Parasequence Set II, Agua de Heredia. F. Massive to crudely laminated gray mudstones with occasional diagenetic nodule-rich horizons (FA6 Distal offshore). Parasequence Set II, Agua de Heredia. See Table 1 for more details about their main attributes, and Figs. 2 and 4 for location in stratigraphy. 


\subsection{Lower shoreface (FA3)}

FA3 mostly comprises tabular very fine- to fine-grained sandstones with HCS, and subordinated SCS, plane bed, and symmetrical ripples (Fig. 5C). Bioturbation intensity ranges significantly (BI 2-5) and is dominated by the Skolithos ichnofacies (Table 1). This association is interpreted as a lower-shoreface setting dominated by deposits related to storm-surge, purely oscillatory or combined flows (Walker and Plint, 1992; Dumas and Arnott, 2006) with high re-mobilization potential and accordingly, low preservation of fair-weather sediments.

\subsection{Offshore transition (FA4)}

FA4 consists of tabular and massive muddy sandstones and subordinated sandy mudstones (Fig. 5D). Muddy sandstones have up to $30 \%$ mud and terrigenous coarse silt and very find sands dominate, whereas in sandy mudstones the mud fraction is estimated in about 50 to $70 \%$. Bioturbation was mostly intense (BI 5-6), locally moderate (BI 4). A highly diverse Cruziana ichnofacies dominates (Table 1) in which Teichichnus and Chondrites prevail (Fig. 6A, B). Infrequently, medium- to thin-bedded, very-fine grained sandstones with HCS are recorded in this association. These beds invariably show an increment of bioturbation intensity at the top, passing abruptly to completely bioturbated muddy sandstones. This association is inferred to represent an offshoretransition setting, immediately below the fair-weather wave-base (Reading and Collinson, 1996; Schwarz et al., 2013). Storm-surge flows delivered sand to distal marine settings, but post-depositional bioturbation mixed mud and sandy event beds into muddy sandstones in almost all cases.

\subsection{Proximal offshore (FA5)}

FA5 is dominated by massive sandy and silty mudstones forming tabular beds with diffuse bedding planes (Fig. 5E). Bioturbation intensity is systematically high (BI 5-6). Ichnologically, a distal expression of the Cruziana ichnofacies is encountered (Table 1). Chondrites, Rhizocorallium, and Zoophycos sporadically occur in outcrops (Fig. 6C, D), whereas smaller traces such as Phycosiphon or Helminthopsis are commonly observed in cores of these sandy and silty mudstones (Veiga et al., 2013, their Fig. 9c). As in FA4, very uncommon discrete sandstone beds occur interbedded in this association, but they tend to be finer grained and thinner than the ones interbedded in that facies association (Table 1). Due to the relatively lower proportion of sand in this association than in FA4, FA5 is interpreted as a proximal-offshore setting, representing the distal end of the running-distance of most stormderived flows (Veiga et al., 2013).

\subsection{Distal offshore (FA6)}

FA6 includes mudstone-dominated successions that are common at the base and top of the study interval (Fig. 2, 5F). At the base, they consist of gray, massive, moderately bioturbated mudstones, grouped into the Zoophycos ichnofacies (Table 1) that is commonly observed in cores (Veiga et al., 2013, their Fig. 9D). Medium- to thin-bedded
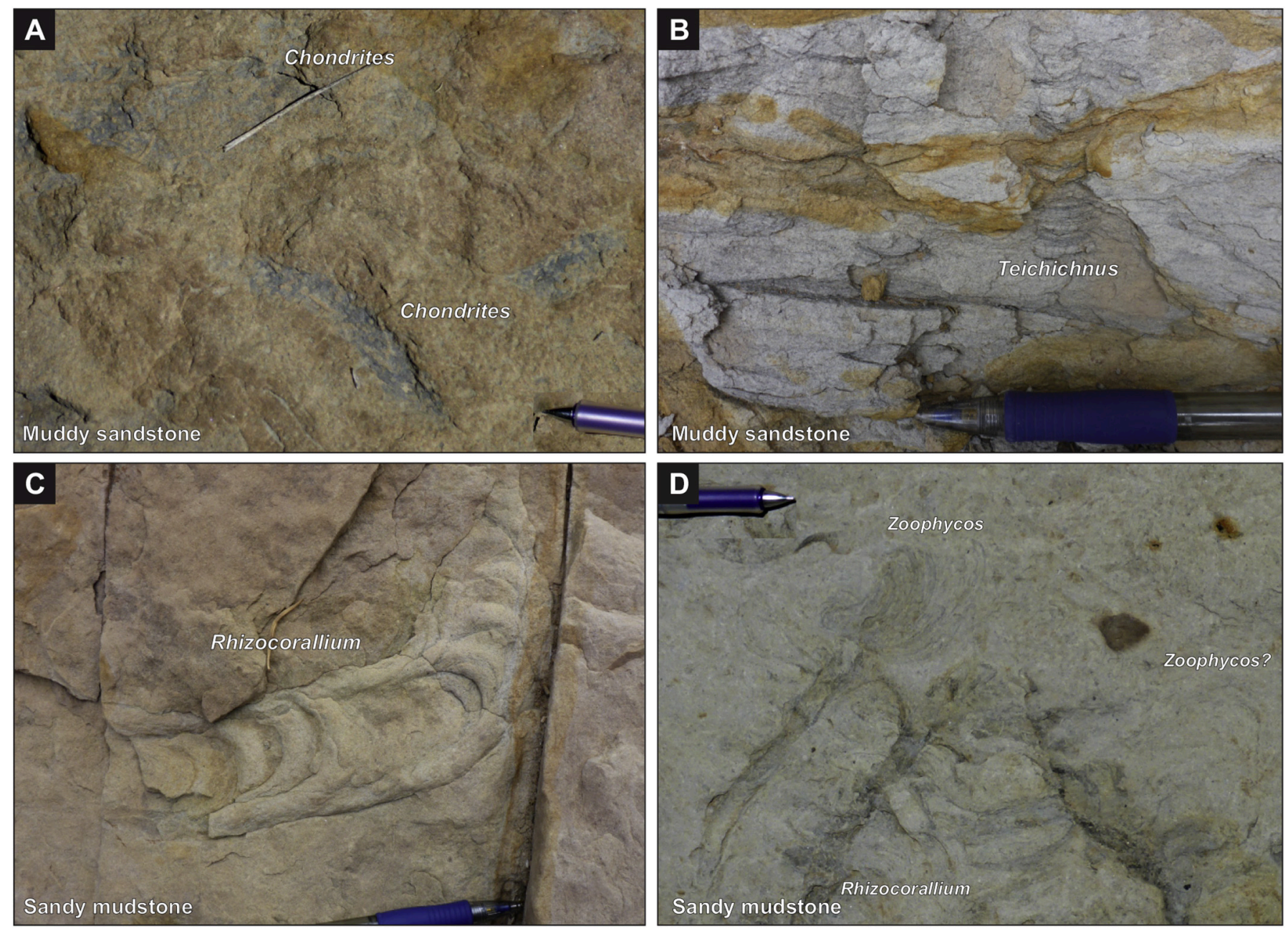

Fig. 6. Selected examples of trace fossils found in offshore transition (FA4) and proximal offshore (FA5) facies associations. 
conglomerate layers with extraformational pebbles and mudstone rip-up clasts are locally interbedded in these mudstone beds. At the top of the unit, towards the Los Molles Formation, FA6 is mostly represented by black, fissile (platy), unbioturbated shales in which cm-thick tuffaceous layers occur. FA6 is interpreted to reflect the distal conditions of an offshore to shelf setting, but under two different conditions: the oxic seafloor conditions as well as sediment gravity flows depositing coarse material were common when the distal offshore deposits of the early Bardas Blancas Formation accumulated; the overlying Los Molles Formation, however, exhibit high organic contents and original lamination that points to long-lived dysoxic to anoxic conditions (Doyle et al., 2005; Veiga et al., 2013).

\subsection{Depositional model}

Except for FA1 that is solely recorded at the base of the Bardas Blancas Formation (Table 1), the remaining facies associations are commonly stacked to form up to a few tens of meters thick shallowingupward successions. Thus, a well-defined storm- and wave-dominated shoreface-offshore depositional system is reconstructed for the unit (Fig. 7). The upper-shoreface was dominated by migrating dunes and bars associated with long-shore currents (FA2), whereas the adjacent lower-shoreface setting mostly exhibits event beds with HCS formed by the development of storm-surge combined flows (FA3, Fig. 7). The bioturbation intensity within the shoreface deposits increases offshore and hence, follows the normal pattern for wave-dominated shorefaceoffshore systems (Howard and Reineck, 1981; Walker and Plint, 1992; Gowland, 1996; Hampson, 2000; MacEachern et al., 2007; Schwarz et al., 2016, 2018).

In marked contrast, the preservation motifs and inferred conditions in the offshore transition (FA4) and proximal offshore (FA5) appear quite peculiar. These two adjacent settings record depositional conditions between fair-weather and storm wave-base (Fig. 7), and show a gradual increase in the proportion of mud versus sand fraction, because the storm-surge flows could export decreasing amounts of sand to more distal areas (Aigner and Reineck, 1982; Plint, 2010). With respect to the post-depositional mixing of mud and sand, these two environments are very similar, providing a similar capacity of burrowing organisms to rework almost $100 \%$ of the sands between the events. The fact that these conditions prevailed for a long period of time (7 to $10 \mathrm{Myr}$ ) is not a commonly reported motif for examples worldwide and is further discussed in this contribution.

In the distalmost segment of the interpreted shoreface-offshore system, accumulation of mud prevailed and is considered to have been accumulated dominantly from settling out of suspensions in very lowenergy hydrodynamic settings (FA6). Debris flows transporting gravel were common in early stages of the system (Fig. 7), but probably became infrequent later in its evolution, allowing to produce a mud-rich, distal

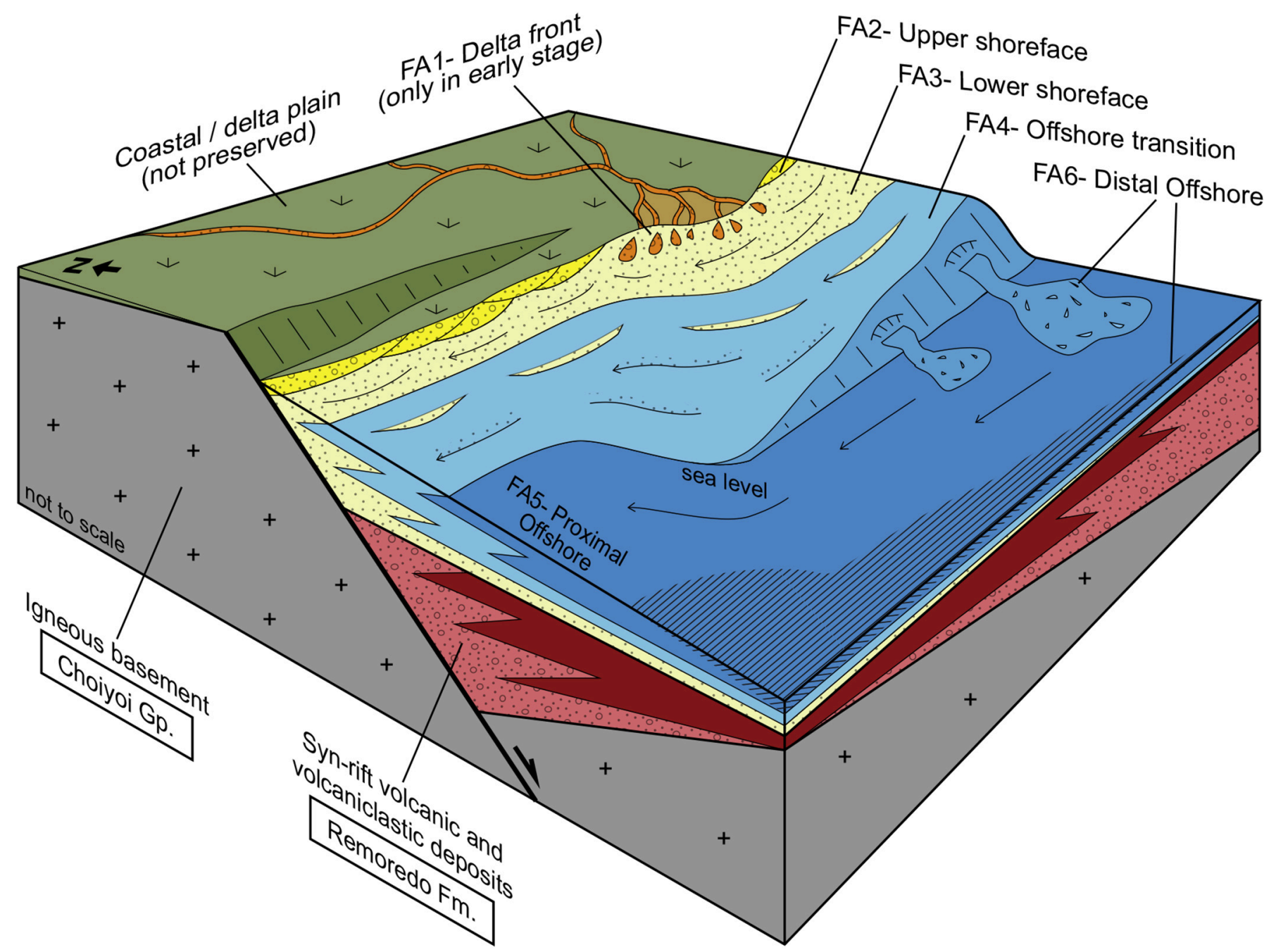

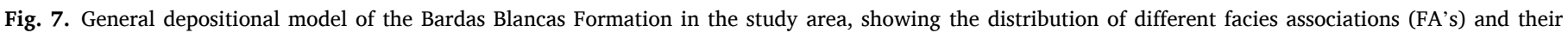

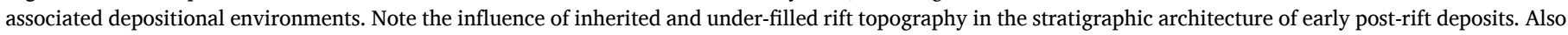
note that the fluvial entry point and deltaic system within the study area would apply for the early stages of evolution. Not to scale. 
offshore, occasionally colonized by Zoophycos-producing organisms. Distal offshore settings prevailed further to the west of the study area were substrate conditions probably remained constant during most of the Bardas Blancas Formation deposition (Figs. 2, 7). When a distal offshore setting was established in the southern sector of the study area (Los Molles Formation), a shift to prevailing dysoxic-anoxic conditions appears to have dominated in the sea-floor.

\section{Architecture of an intensely bioturbated succession}

The shallowing-upward units identified in the Bardas Blancas are parasequences bounded by flooding surfaces (Figs. 4, 8A), uncommonly demarcated by shell beds. These stratigraphic units are internally composed of bedsets with subtle stratigraphic boundaries (Fig. 8A). In the lower interval of the unit, parasequences show a complete transition
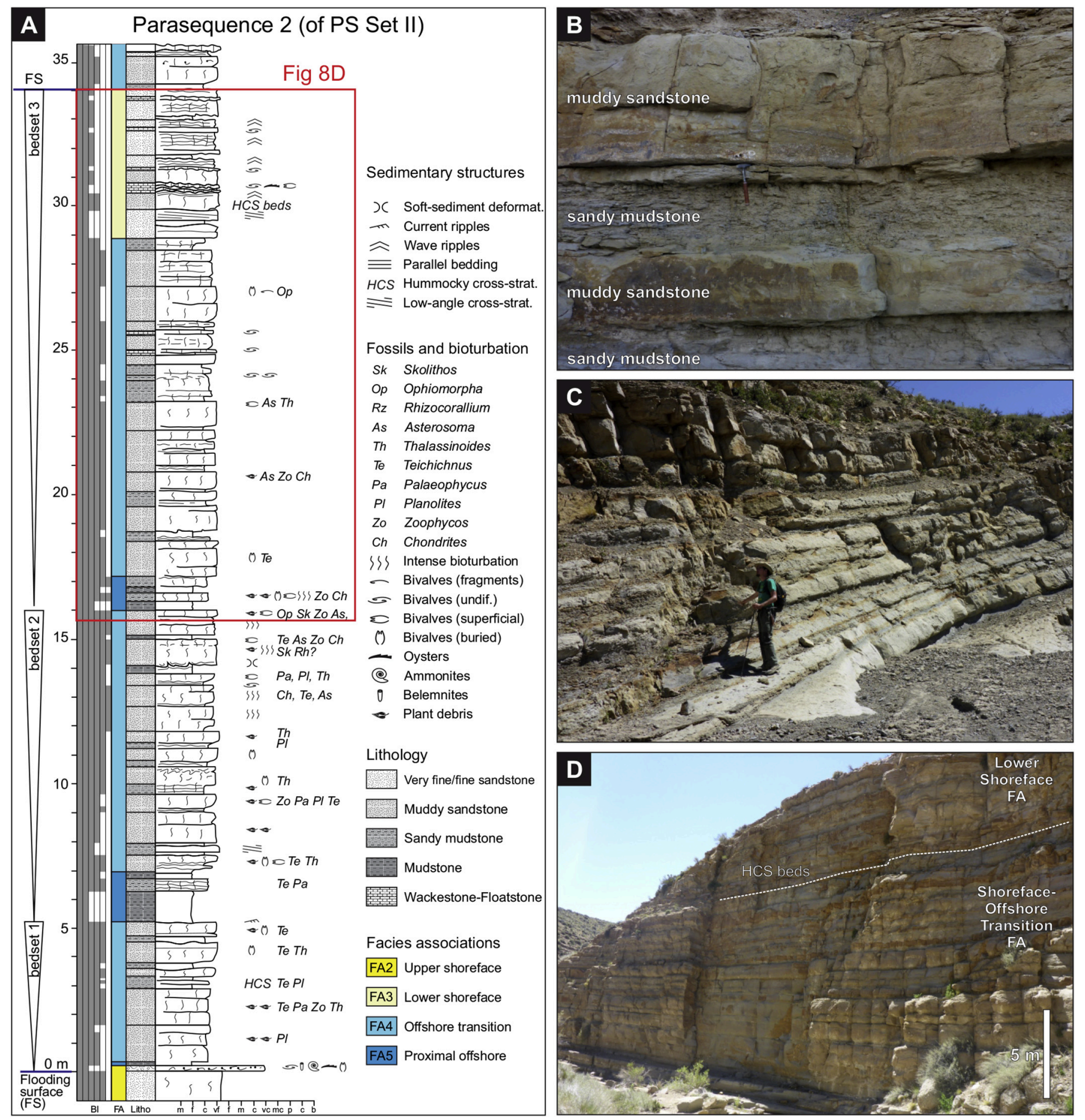

Fig. 8. Architecture, bedding and bioturbation of the study interval at different scales. A. Detailed stratigraphic section with the lithological, sedimentary and bioturbation trends of a 10's of m-thick, shallowing-up succession (parasequence), made by several m-scale bedsets, and bounded by regional-scale flooding surfaces. Parasequence Set II, Agua de Heredia. See Figs. 2 and 4 for location in stratigraphy. B. Highly bioturbated, dm-scale muddy sandstones and sandy mudstones in offshore transition deposits (FA5). Parasequence Set III, Agua del Naco. C. Bioturbated offshore transition deposits (FA5), stacked in m-scale, well-defined bedsets. Parasequence Set III, Agua de Ñaco. D. General view of several m-scale bedsets, showing the homogeneous and tabular nature of the studied deposits. Parasequence Set II, Agua de Heredia. See stratigraphic position in A. 
from mudstones of FA6 (distal offshore) to clean, trough cross-bedded sandstones of FA2 (upper shoreface) (Fig. 4). In the middle and upper intervals of the Bardas Blancas Formation, parasequences are mostly composed of sandy mudstones and muddy sandstones of FA5 and FA4 (proximal offshore and offshore transition), sometimes with the presence of lower-shoreface HCS-sandstones at their top (FA3) (Figs. 8A). Bioturbation intensity in the lower-shoreface deposits is either similar or lower than the one recorded in the underlying offshore-transition facies
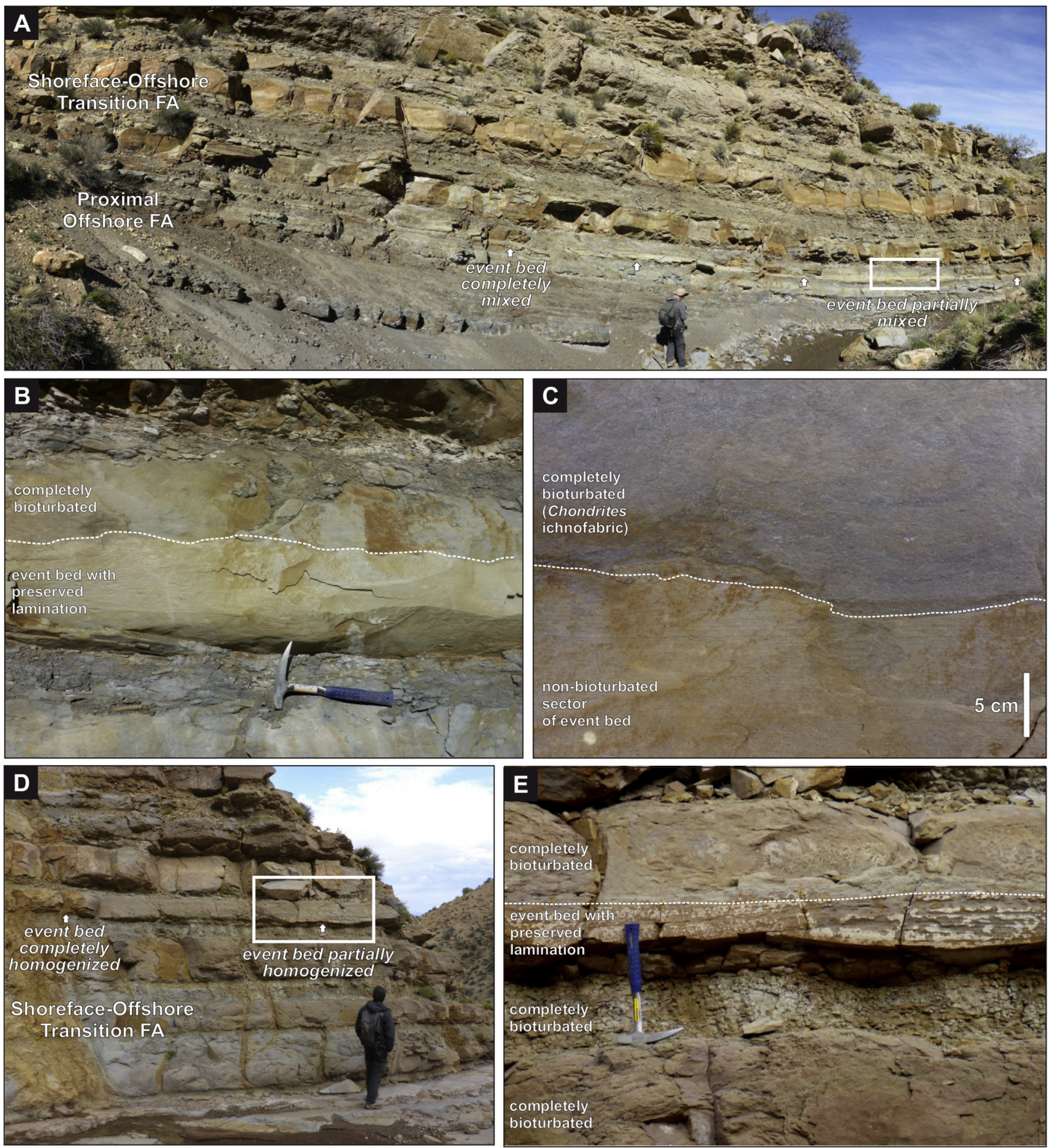

Fig. 9. Two examples of preserved HCS in storm beds. A. General view of the gradual vertical transition from proximal offshore (FA5) to offshore transition deposits (FA4). B. Example of partially preserved HCS in dominantly highly bioturbated proximal offshore deposits (FA5). Parasequence Set II, Agua de Heredia. C. Detailed view of the contact between the fully bioturbated (Chondrites ichnofabric) upper part and the non-bioturbated lower part (preserving the original sedimentary structures) of the same event bed. Parasequence Set II, Agua de Heredia. D. Outcrop view of offshore transition deposits (FA4). E. Example of preserved HCS in a partially mixed event bed, overlain and underlain by highly bioturbated muddy sandstones and sandy mudstones (offshore transition, FA4). Parasequence Set III, Agua del Campo Sur. 
(Fig. 8A).

The most distinctive feature of the Bardas Blancas Formation is that most of the proximal offshore (FA5) and offshore transition (FA4) strata are intensely bioturbated (BI 5-6). Complete bioturbation (BI 6) is dominant and results in a completely structureless appearance of the beds (Fig. 8B, Taylor and Goldring, 1993; Wetzel and Uchman, 1998). It also typically prevents the identification of individual trace fossils. In these two facies associations, beds are defined by subtle variation in the sand-silt-mud content, usually aided by the weathering profile, where the muddier facies is less resistant (Fig. 8B). The relative dominance of muddy sandstones versus sandy and silty mudstones in a given interval defines the presence of FA4 or FA5 (Fig. 8B, C). Individual beds range from $0.10 \mathrm{~m}$ up to $1.5 \mathrm{~m}$ in thickness and they almost invariably show planar, horizontal lower and upper contacts defining tabular beds at different scales, from a few 10 s to $100 \mathrm{~s}$ of meters in length (Fig. 8C, D).

Despite the intense bioturbation, these two facies associations
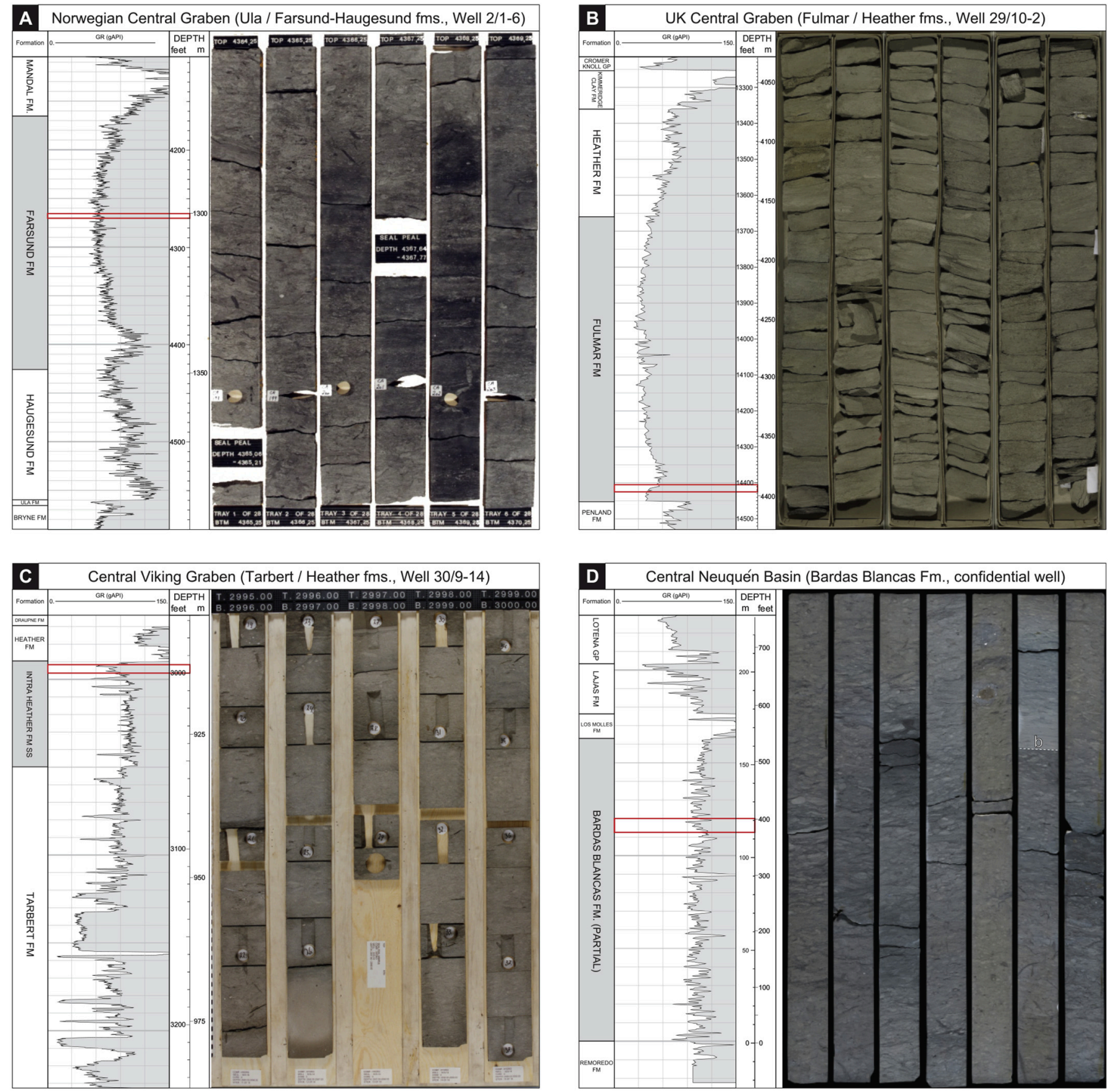

\section{cored interval shown}

Fig. 10. GR well logs and core examples of highly bioturbated, storm-dominated shallow-marine successions comparable to the studied deposits. A. Upper Jurassic Farsund Formation, interpreted as the equivalent offshore transition deposits of the bioturbated, sand-rich Ula Formation in the Norwegian Central Graben. B. Heather and Intra-Heather Sandstone Formation, the offshore transition deposits overlying the transgressive shallow-marine sandstones of the Tarbert Formation, in Northern Viking Graben/Western Horda Platform. C. Heather Formation, also the equivalent offshore transition deposits of the highly bioturbated, Fulmar Formation, in the UK Central Graben. D. Lower-Middle Jurassic Bardas Blancas Formation, Neuquén Basin (this study). b: partially preserved event bed. 

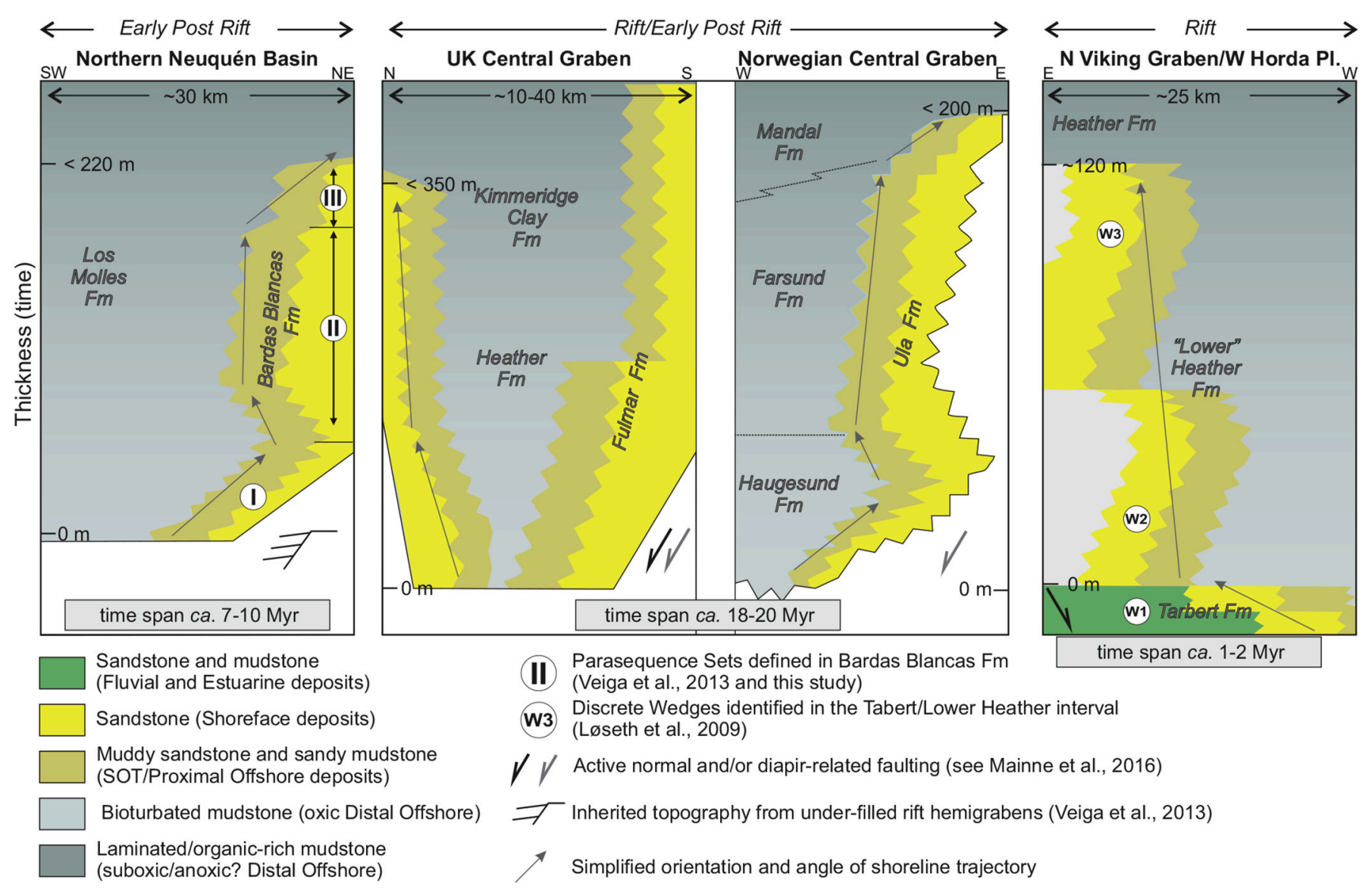

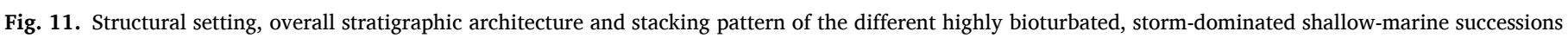
shown in Fig. 10, and the Bardas Blancas Formation. Y-axis represents thickness of the successions.

contain sparsely unbioturbated sandstone beds providing information for interpreting their primary depositional processes. Where observed, these sandstone beds commonly have hummocky cross-stratification and are laterally continuous for up to a few 10s of meters (Fig. 9A, D). They have a sharp, irregular base overlying silty mudstone and invariably show an irregular, transitional or sharp top to muddy sandstones (Fig. 9B, E). In these overlying muddy sandstone, biotubation intensity is moderate to high (BI 4-5), and an ichnofabric dominated by Chondrites can be recognized in outcrop (Fig. 9C); however, a more diverse assemblage including Phycosiphon and Zoophycos has also been recorded in cores of the unit (Veiga et al., 2013). The discrete storm-generated deposit rapidly becomes a completely bioturbated muddy sandstone laterally, and exhibits the typical weathering profile as all of the similar beds (Fig. 9A, D).

The aggradational to retrogradational stacking pattern of Parasequence Sets II and III has a major impact in the resulting distinctive stratigraphic architecture of the study succession (Figs. 2, 4). As a result of these long-term aggradational conditions, about $100 \mathrm{~m}$ of the Bardas Blancas Formation in the study area are dominated by a vertical stacking of almost completely mixed deposits of FA4 and FA5 (Figs. 4, 8 and 9). The resulting stratigraphy is a storm-generated, but highly bioturbated, thick monotonous succession, with very little grain size variation (muddy sandstones to sandy mudstones), virtual absence of preserved primary physical (sedimentary) structures, bedding contacts that are invariably horizontal, and scattered fossil remains that rarely produce distinct shell concentrations.

\section{Discussion}

The preservation potential of individual storm-related event beds (or tempestites) in shallow-marine settings and the lam-scram textures resulting from partial to total biogenic reworking of these event beds have been extensively reported and discussed (Wheatcroft, 1990; MacEachern and Pemberton, 1992; among many others). Three types of shoreface settings are distinguished based on the intensity and frequency of storms: intense, moderate, and weak or low-energy (MacEachern and Pemberton, 1992). Commonly is assumed that a thoroughly bioturbated succession with little or no preserved tempestites within a storm-influenced shoreface-offshore system would represent weakly storm-affected shoreface facies dominated by fair-weather deposits. Following this reasoning, stacked, well-preserved tempestites would be interpreted as storm-dominated shoreface deposits (MacEachern and Pemberton, 1992; MacEachern et al., 1999; Pemberton et al., 2012).

The facies associations interpreted to represent offshore-transition (partially equivalent to the "distal lower shoreface" of MacEachern et al., 1999) to proximal offshore settings of the Bardas Blancas Formation are invariably composed of highly bioturbated muddy sandstones, sandy mudstones, and very few preserved tempestites. Most, if not all, of the presently bioturbated deposits were delivered by stormsurge flows. Following the MacEachern and Pemberton (1992) characterization, the Bardas Blancas system would, therefore, match the lowenergy category of the storm-influenced shoreface systems.

\subsection{Thick bioturbated storm-influenced shallow-marine successions: Where do they occur?}

Monotonous, more than $100 \mathrm{~m}$ thick successions of storminfluenced, shallow-marine deposits formed by persistent combination of processes that resulted in highly bioturbated strata are not common in 
Table 2

Main characteristics of the thick, intensely bioturbated successions discussed in this contribution.

\begin{tabular}{|c|c|c|c|c|c|c|}
\hline Units & $\begin{array}{l}\text { Age; } \\
\text { Duration; } \\
\text { Thickness }\end{array}$ & $\begin{array}{l}\text { Dominant facies (in lower } \\
\text { shoreface and offshore- transition } \\
\text { settings) }\end{array}$ & $\begin{array}{l}\text { Long-term } \\
\text { Stacking Pattern }\end{array}$ & $\begin{array}{l}\text { Tectonic setting and } \\
\text { subsidence }\end{array}$ & Sediment source & References \\
\hline $\begin{array}{l}\text { Emery Sandstone } \\
\text { (Mancos Shale } \\
\text { Fm., Utah, USA) }\end{array}$ & $\begin{array}{l}\text { Upper } \\
\text { Cretaceous; } \\
1.8 \mathrm{Myr} \\
<250 \mathrm{~m}\end{array}$ & $\begin{array}{l}\text { Intensely bioturbated fine to } \\
\text { medium grained sandstones; } \\
\text { interbedded siltstones }\end{array}$ & Aggradational & $\begin{array}{l}\text { High subsidence rates in } \\
\text { foreland basin setting }\end{array}$ & $\begin{array}{l}\text { Small rivers, little evidence } \\
\text { of deltaic influence, low } \\
\text { sedimentation rates } \\
\text { compared to underlying and } \\
\text { overlying units. }\end{array}$ & $\begin{array}{l}\text { Edwards et al. } \\
(2005)\end{array}$ \\
\hline $\begin{array}{l}\text { Ula and Farsund } \\
\text { formations } \\
\text { (Norwegian } \\
\text { Central Graben) }\end{array}$ & $\begin{array}{l}\text { Upper } \\
\text { Jurassic; } \\
\text { ca. } 18.5 \mathrm{Myr} \\
<200 \mathrm{~m}\end{array}$ & $\begin{array}{l}\text { Intensely bioturbated very fine to } \\
\text { fine grained sandstones (Ula Fm); } \\
\text { intensely bioturbated muddy } \\
\text { sandstones, sandy mudstones, silty } \\
\text { mudstones, and shales (Farsund } \\
\text { Formation) }\end{array}$ & $\begin{array}{l}\text { Aggradational, } \\
\text { retrogradational }\end{array}$ & $\begin{array}{l}\text { Series of extensional fault- } \\
\text { bounded basins and sub- } \\
\text { basins, relative high } \\
\text { mechanical subsidence }\end{array}$ & Not available & $\begin{array}{l}\text { Baniak et al. } \\
(2014,2015) \text {. }\end{array}$ \\
\hline $\begin{array}{l}\text { Fulmar Fm. and } \\
\text { equivalent } \\
\text { Header Fm. (UK } \\
\text { Central Graben) }\end{array}$ & $\begin{array}{l}\text { Middle- } \\
\text { Upper } \\
\text { Jurassic; } \\
\text { ca. } 21.1 \mathrm{Myr} \\
<360 \mathrm{~m} \\
\text { (typically } \\
60-110 \mathrm{~m} \text { ) }\end{array}$ & $\begin{array}{l}\text { Moderate to Intensely bioturbated } \\
\text { fine to medium grained } \\
\text { sandstones, uncommon HCS- } \\
\text { sandstone beds; intensely } \\
\text { bioturbated muddy heterolithics }\end{array}$ & Aggradational & $\begin{array}{l}\text { Mechanical subsidence } \\
\text { and/or diapir- related } \\
\text { faulting, complex } \\
\text { topography linked to sub- } \\
\text { basins and intrabasinal } \\
\text { highs. }\end{array}$ & $\begin{array}{l}\text { Poorly developed river } \\
\text { systems; lack large deltaic } \\
\text { systems; }\end{array}$ & $\begin{array}{l}\text { Gowland } \\
\text { (1996); } \\
\text { Howell and } \\
\text { Flint (1996) }\end{array}$ \\
\hline $\begin{array}{l}\text { Tarbert - Lower } \\
\text { Heather } \\
\text { formations } \\
\text { (northern North } \\
\text { Sea) }\end{array}$ & $\begin{array}{l}\text { Middle } \\
\text { Jurassic; < } \\
4.2 \mathrm{Myr} ; \\
<200 \mathrm{~m}\end{array}$ & $\begin{array}{l}\text { Bioturbated and HCS-dominated } \\
\text { very fine to medium grained } \\
\text { sandstone; bioturbated silstones }\end{array}$ & Retrogradational & $\begin{array}{l}\text { Series of extensional fault- } \\
\text { bounded basins and sub- } \\
\text { basins, relative high } \\
\text { mechanical subsidence }\end{array}$ & Not available & $\begin{array}{l}\text { Løseth et al. } \\
\text { (2009) }\end{array}$ \\
\hline $\begin{array}{l}\text { Bridport Sand Fm. } \\
\text { (Wessex Basin, } \\
\text { UK) }\end{array}$ & $\begin{array}{l}\text { Early } \\
\text { Jurassic; } \\
\sim 7 \mathrm{Ma} \\
<200 \mathrm{~m}\end{array}$ & $\begin{array}{l}\text { Silty, very fine to fine grained } \\
\text { sandstones }\end{array}$ & $\begin{array}{l}\text { Progradational, } \\
\text { aggradational }\end{array}$ & $\begin{array}{l}\text { Extensional fault-bonded } \\
\text { depocentres; } \\
\text { high rates of mechanical } \\
\text { subsidence }\end{array}$ & $\begin{array}{l}\text { Lack of river-mouth } \\
\text { processes; along-shore } \\
\text { transport significant; high } \\
\text { net siliciclastic sediment } \\
\text { input }\end{array}$ & $\begin{array}{l}\text { Morris et al., } \\
2006\end{array}$ \\
\hline $\begin{array}{l}\text { Bardas Blancas } \\
\text { Fm. (Nequén } \\
\text { Basin, } \\
\text { Argentina) }\end{array}$ & $\begin{array}{l}\text { Lower to } \\
\text { Middle } \\
\text { Jurassic; } \\
\sim 7-10 ; \\
<220 \mathrm{~m}\end{array}$ & $\begin{array}{l}\text { Intensely bioturbated sandy } \\
\text { mudstones, muddy sandstones, } \\
\text { very fine to fine grained } \\
\text { sandstones }\end{array}$ & $\begin{array}{l}\text { Aggradational, } \\
\text { Retrogradational }\end{array}$ & $\begin{array}{l}\text { Underfilled rift } \\
\text { depocentres; inherited } \\
\text { topography }\end{array}$ & $\begin{array}{l}\text { Lack of river-mouth } \\
\text { processes; along-shore } \\
\text { transport significant }\end{array}$ & $\begin{array}{l}\text { Veiga et al., } \\
\text { 2013; this } \\
\text { study }\end{array}$ \\
\hline
\end{tabular}

the stratigraphic record, but they tend to be restricted to certain conditions (Figs. 10, 11; Table 2). The Upper Jurassic Farsund Formation in the Norwegian Central Graben (distal equivalent of the Ula Formation, Bergan et al., 1989; Fraser et al., 2003), the Upper Jurassic Heather and Lower Kimmeridge Clay formations in the UK Central Graben (distal equivalents of the Fulmar Formation, Donovan et al., 1993; Gowland, 1996), and the transition from the Middle Jurassic Tarbert to Heather Formations in the North Viking Graben (Ravnås et al., 1997; Ravnås and Steel, 1998; Løseth et al., 2009) are all subsurface examples showing facies and bioturbation patterns that are remarkably similar to the ones observed in outcrops and subsurface for the Bardas Blancas Formation (Fig. 10D). The Lower to Middle Jurassic Bridport Sand Formation in the Wessex Basin (Morris et al., 2006) and the Upper Cretaceous Emery Sandstone Member of the Mancos Shale (Edwards et al., 2005) provide outcrop examples of highly bioturbated shallow-marine successions.

The Farsund Formation in the Norwegian Central Graben is dominated by intensely bioturbated muddy sandstones and sandy mudstones reaching $200 \mathrm{~m}$ in thickness in Well 2/1-6 (Fig. 10A) (FactPages Norwegian Petroleum Directorate, 2020). The equivalent more proximal Ula Formation is mostly composed of highly bioturbated sandstones, interpreted to reflect weak to moderate shoreface types (Baniak et al., 2014, 2015), following the model from MacEachern and Pemberton (1992). The sedimentology and ichnology of the Fulmar Formation in the UK Central Graben has been described in detail by Howell and Flint (1996) and Gowland (1996). They concur on the long-lived development of a storm-influenced shoreface-offshore system, in which intense bioturbation extinguished depositional structures largely in the lower shoreface and offshore-transition settings (Fig. 10B). As in the Ula Formation, intense bioturbation in the offshore transition zone of the Fulmar Formation was interpreted as the result of low magnitude and/or low frequency of storm events (Howell and Flint, 1996). Collectively, these Upper Jurassic units of the Central Graben developed in a rifting regime and show long-term (several million years) aggradational to retrogradational stacking patterns (Howell and Flint, 1996; Mannie et al., 2014, 2016) (Fig. 11).

The facies associations and stacking patterns of the Tarbert and Lower Heather succession in the North Viking Graben were described by Løseth et al. (2009), based on cores and several key wells including well 30/9-14 (Fig. 10C). In this well, the gamma-ray log for most of the Lower Heather interval shows a very uniform response and cores display relatively homogeneous, highly bioturbated muddy sandstones (Fig. 10C) grading into bioturbated sandstones with poorly preserved HCS beds. This uppermost succession has been interpreted to represent a parasequence with progradation from offshore, into offshore-transition settings and lowermost shoreface, within a long-term retrogradational stacking pattern (Løseth et al., 2009) (W3 in Fig. 11). These authors suggested that bioturbation intensity increases from W2 to W3 within the retrogradational stacking pattern (Løseth et al., 2009, their Fig. 4). This net transgressive trend developed within a syn-rift setting during the Bathonian and probably lasted for 1-2 Myr (Mannie et al., 2016).

The Lower to Middle Jurassic Bridport Sand Formation in the Wessex Basin (UK) is another example of a storm-influenced, intensely bioturbated succession (Morris et al., 2006). According to the high degree of biogenic reworking, the dominant siltstones and silty sandstones with uncommon preserved storm beds were interpreted as reflecting lowenergy lower-shoreface and offshore-transition settings (Morris et al., 2006). Interestingly, no evidence of nearby fluvial influence or rivermouth processes were recorded, and sand supply to the shoreface settings was related to along-shore transport. Moreover, the unit was attributed to represent a long-term aggradational stacking pattern developed in an extensional fault-bounded depocentre, formed due to localized high tectonic subsidence (Morris et al., 2006) (Table 2). A well exposed example of thick, highly bioturbated storm-influenced shallowmarine deposits occurs within the Upper Cretaceous Emery Sandstone 
Member of the Mancos Shale (Book Cliffs, Utah, USA). This units is up to $250 \mathrm{~m}$ thick and represents an aggradational stack of storm-dominated shoreface parasequences developed in a foreland basin (Edwards et al., 2005) (Table 2).

All of these examples illustrate that the Bardas Blancas Formation is a good analogue for thick bioturbated shallow-marine successions occurring in a variety of basinal settings, but preferentially in those where: (1) storm-surges act as main across-offshore transport within relatively confined or small marine depocentres, (2) the fluvial influence is low to moderate, and (3) on the long-term the sediment supply and accommodation is balanced and expressed by aggradational stacking patterns (Fig. 11). Thus, it is an oversimplification to assume that these depositional conditions would be overruled by the frequency and magnitude of atmospheric processes (such as the storms), which also vary significantly during the long-term periods represented by these successions.

\subsection{Factors fostering thick bioturbated storm-influenced shallow-marine successions}

Based on the occurrence of similar, thick, storm-generated, shallowmarine successions sharing more geological attributes than just their highly bioturbated nature, we propose to relate the intense bioturbational mixing of the original storm beds and sedimentary structures over several million years to a suite of factors, rather than constant low frequency and/or magnitude of atmospheric processes (the storms).

Most of the examples mentioned above are related to complex synrift or early post-rift topography, which defines relative small depocentres during long-term marine transgressions (Howell and Flint, 1996; Veiga et al., 2013). These depocentres were mostly elongated and a few to tens of kilometers wide (Fig. 11). This depositional context is essential for the benthic fauna to inhabit almost the entire extent of these small depocentres, to produce not only total bioturbation in vertical sections (as seen in 1D cores, Fig. 10), but also to obliterate original beds for several kilometers laterally, as recorded in the outcrops of the Bardas Blancas Formation. In other words, we relate the relatively small size of the depositional setting to the high efficiency of benthic fauna to rework most of the individual storm deposits, independently of how fast the benthos establishes on the event bed, or the storm frequency. This bioturbational mixing efficiency is steadily high across the depositional environment, from the lower shoreface to proximal offshore, and does not necessarily follow the trends observed on modern shelves (Reineck, 1977; Howard and Reineck, 1981). Howell and Flint (1996) already used this basin-scale factor to support their process-realistic depositional model for the bioturbated, sand-dominated deposits of the Fulmar Formation. Moreover, Morris et al. (2006) suggested that small areas of accumulation in the Bridport Formation could have been more prone to extensive biotic proliferation, increasing the destruction success of storm-event beds. Going further, it can be speculated that relatively small-sized depocentres would allow a more homogeneous distribution of the food source for the benthic fauna, which would ultimately account for its success in utilizing the entire depositional setting at all times.

An additional, long-term control on these thick bioturbated successions is related to the potential riverine water, sediment, and solute input to the marine realm. Modern studies have shown that individual, hurricane-related storm-event beds have high probability to be completely destroyed by bioturbation when riverine influence is relatively low and water depth is shallow $(<30 \mathrm{~m})$, for example in the inner shelf of the Gulf of Mexico (Snedden and Nummedal, 1991; Dashtgard et al., 2015). Likewise, it has also been recently demonstrated that amalgamated storm beds can be completely bioturbated fairly rapidly $(<10$ years) under conditions of high riverine influence, such as several hurricane-event layers described immediately downdrift of the Missisippi River delta, in similar water depths (Walsh et al., 2018).

The stratigraphic record of the intensely bioturbated succession reported in our study suggests a sustained biogenic reworking efficiency close to $100 \%$ during several million years (Fig. 11). Consequently, ecologic factors affecting the benthic fauna typically associated with nearby, high riverine influence, such as turbidity or salinity fluctuations, were short-lived or uncommon episodes in the reported depositional settings. Therefore, for most of the Bardas Blancas Formation (PS Sets II and III, Fig. 4) we infer that riverine entry points were far from the study area and sand was supplied mostly by along-shore transport. This seems to be the case also for other examples discussed in section 6.1 and shown in Table 2. Howell and Flint (1996) inferred absence of large deltas and low-discharge fluvial systems to deliver the clastic supply for the marine sandstones of the Fulmar Formation, whereas Morris et al. (2006) related the highly bioturbated succession to the lack of nearby rivermouth processes and significant along-shore transport. Significantly, the intensely bioturbated Emery Member was formed when small rivers drained the Sevier Orogen, rather than a large fluvial system as inferred for the shoreface settings of the underlying and overlying units (Edwards et al., 2005).

Another evident similarity between all the aforementioned examples is associated with the long-term stacking pattern (Fig. 11). The early post-rift Bardas Blancas Formation and the rift to early post-rift successions of the Central Graben show a consistent aggradational to retrogradational stacking covering from 7 to 20 Myr (Fig. 11) (Table 2). The transition from the fluvial to estuarine deposits of the Tarbert Formation and thereafter into the marine deposits of the lower Heather Formation, represents at the base a net retrogradational trend that becomes more aggradational-to-retrogradational upward (W2 and W3, Fig. 11). Interestingly, the overall bioturbation index in the offshoretransition deposits increases in the W3 interval (Løseth et al., 2009), suggesting that the maximum bioturbational mixing efficiency of stormevent beds occurred at that time.

The Emery Sandstone succession represents another unusual record of long-term aggradational stacking pattern (1.7 Myr, Table 2), in which the sedimentation rates were low compared to those of the underlying and overlying units (Edwards et al., 2005). Coincidently, the offshoretransition to lower-shoreface deposits of the Emery Sandstone reflect one of the highest bioturbational mixing efficiency of storm-event beds in the Upper Cretaceous record of the Wasatch-Book Cliff section (Edwards et al., 2005). This shows a marked difference with less bioturbated, environment-equivalent deposits, for example the younger Kenilworth Member (Eide et al., 2015) and the Grassy Member (Onyenanu et al., 2018) of the Blackhawk Formation, both units developed in progradational stacking patterns. Thus, a delicate long-lived balance between sediment supply and accommodation to create thick successions with highly aggradational (to slightly retrogradational) stacking patterns could be linked to sedimentation rates across the shorefaceoffshore system. The offshore-transition and proximal offshore sectors of the system would have experienced low net sedimentation rates that if all other variables remained fairly constant - would have produced a similar effect than low frequency storm-surge flows reaching those regions. The lack of significant progradational events expressed by basinward facies shifts also contributed to create thick, fairly homogeneous strata, without major breaks in sedimentation or sequence boundaries, and representing only one or two segments of the depositional system. In the case of the investigated examples, those segments correlated approximately with the areas between the fair-weather and the storm wave-base, in which the highest bioturbational mixing efficiency of storm-event beds took place.

By combining the observations and interpretations of different thick, intensely bioturbated, shallow-marine successions the common assumption that the final bioturbated product can be associated only to low frequency or magnitude of storm events is questionable. Alternatively, the long-lived efficiency of benthic fauna reworking most if not all the storm-event beds reaching the offshore transition sector, results from the combination of two or three factors: (1) deposition in relatively confined marine depocentres, (2) persistent low fluvial influence, and (3) a long-term, aggradational to slightly retrogradational stacking 
pattern. As these conditions can be develop in a variety of basin styles, such as rift, early post-rift, and foreland settings, the recognition of thick, bioturbated successions as the ones discussed here can be used to infer more realistic constrains for depositional models and to better predict facies distribution in such storm-influenced systems.

\section{Conclusions}

1. The Lower-Middle Jurassic Bardas Blancas Formation represents an up to $220 \mathrm{~m}$ thick, highly bioturbated, storm-influenced shallowmarine succession developed during the early post-rift stage of the Neuquén Basin.

2. Most of its stratigraphic record is dominated by muddy sandstones and sandy to silty mudstones deposited in offshore-transition to proximal-offshore settings, in which benthic- fauna efficiency to rework individual storm-event beds was persistently close to $100 \%$ during a time span ranging from 7 to $10 \mathrm{Myr}$. This highly efficient biogenic reworking was mostly associated to deposit-feeding organisms of the Cruziana ichnofacies.

3. The Bardas Blancas Formation shares several attributes with other $>100$ thick, intensely bioturbated successions including: (i) deposition in relatively confined marine depocentres, (ii) persistent low riverine influence, and (iii) long-term (2-20 Myr) aggradational stacking pattern. Yet, all these biogenically reworked successions are developed in a variety of structural styles, including rift, early postrift, and foreland settings.

4. Therefore, it is questionable to assume that the resulting architecture of these unusually thick, bioturbated shoreface-offshore successions at different scales should be directly associated to low-frequency or magnitude storms. Alternatively, the long-lived efficiency of benthic fauna reworking almost all the storm-event beds formed in these depositional environments during several million years was more likely controlled by the co-occurrence of the following depositional factors: a) relatively small depocenters with infauna evenly distributed in intermediate to distal sectors, b) benthic fauna very rarely affected by considerable physico-chemical changes in those regions due to overall low riverine influence, and c) delicate balance between sediment supply and accommodation producing an aggradational stacking and relatively low net sedimentation rates across the depositional area.

5. These depositional conditions can establish in a variety of basin styles, so the outlined factors controlling the formation of thick, highly bioturbated successions can be applied to infer more realistic constrains for depositional models and improving facies predictions in such confined storm-influenced systems.

\section{Declaration of Competing Interest}

None.

\section{Acknowledgments}

E.S. would like to thank CONICET and Universidad Nacional de La Plata for partially supporting this project. M.P. and I.M. acknowledge Aker BP, sponsor of the ShelfSed project (University of Oslo). We thank J. Cuitiño and A. Weztel for their constructive reviews and specifically the latter for his dedicated revision of the English writing. An anonymous reviewer also provided additional comments. We are also grateful to Francisco Rodriguez-Tovar for the invitation to participate in this special publication.

\section{References}

Aigner, T., Reineck, H.-E., 1982. Proximality trends in modern storm sands from the Helgoland Bight (North Sea) and their implications for basin analysis. Senckenberg. Marit. 14, 183-215.
Arregui, C., Carbone, O., Martínez, R., 2011. El Grupo Cuyo (Jurásico Temprano-Medio) en la Cuenca Neuquina. In: Geología y Recursos Naturales de la Provincia del Neuquén: Buenos Aires, Relatorio del 18 Congreso Geológico Argentino, pp. 77-89.

Baniak, G.M., Gingras, M.K., Burns, B.A., Pemberton, S.G., 2014. An example of a highly bioturbated, storm-influenced shoreface deposit: upper Jurassic Ula Formation, Norwegian North Sea. Sedimentology 61, 1261-1285.

Baniak, G.M., Gingras, M.K., Burns, B.A., Pemberton, S.G., 2015. Petrophysical characterization of bioturbated sandstone reservoir facies in the Upper Jurassic Ula Formation, Norwegian North Sea, Europe. J. Sediment. Res. 85, 62-81.

Bergan, M., Tørudbakken, B., Wandås, B., 1989. Lithostratigraphic correlation of Upper Jurassic sandstones within the Norwegian Central Graben: Sedimentological and tectonic implications. In: Collinson, J.D. (Ed.), Correlation in Hydrocarbon Exploration. Springer Netherlands, Dordrecht, pp. 243-251.

Bressan, G.S., Kietzmann, D.A., Palma, R.M., 2013. Facies analysis of a Toarcian/ Bajocian shallow marine/coastal succession (Bardas Blancas Formation) in northern Neuquén Basin, Mendoza province, Argentina. J. S. Am. Earth Sci. 43, 112-126.

Brinkworth, W., Vocaturo, G., Loss, L., Giunta, D., Mortaloni, E., Massaferro, J.L., 2018. Estudio cronoestratigráfico y evolución paleoambiental del Jurásico Inferior-Medio en el Engolfamiento de la Cuenca Neuquina, Argentina. In: Gardini, M., Gómez, M., Manceda, R., Ayoroa, M.A., Limeres, M., Peroni, G., Villar, H. (Eds.), Sesiones Generales, $10^{\circ}$ Congreso de Exploración y Desarrollo de Hidrocarburos, Mendoza. Instituto Argentino del Petróleo, Argentina, pp. 597-621.

Burgess, P.M., Flint, S., Johnson, S., 2000. Sequence stratigraphic interpretation of turbiditic strata: an example from Jurassic strata of the Neuquén basin, Argentina. GSA Bull. 112, 1650-1666.

Clifton, H.E., Posamentier, H.W., Walker, R.G., 2006. A re-examination of facies models for clastic shorelines. In: Facies Models Revisited. Society for Sedimentary Geology, 84, pp. 293-337. Special Publications.

Cohen, K.M., Finney, S.C., Gibbard, P.L., Fan, J.-X., 2013. The ics international chronostratigraphic chart. Episodes 36, 199-204. V2020/03. WWW.stratigraphy.org

Cristallini, E., Tomezzoli, R., Pando, G., Gazzera, C., Martínez, J.M., Quiroga, J., Buhler, M., Bechis, F., Barredo, S., Zambrano, O., 2009. Controles Precuyanos en la estructura de la Cuenca Neuquina: Rev. Asoc. Geol. Argent. 65, 248-264.

Dashtgard, S.E., Snedden, J.W., MacEachern, J.A., 2015. Unbioturbated sediments on a muddy shelf: Hypoxia or simply reduced oxygen saturation? Palaeogeogr. Palaeoclimatol. Palaeoecol. 425, 128-138.

D’Elia, L., Bilmes, A., Franzese, J.R., Veiga, G.D., Hernández, M., Muravchik, M., 2015. Early evolution of the southern margin of the Neuquén Basin, Argentina: tectonostratigraphic implications for rift evolution and exploration of hydrocarbon plays. J. S. Am. Earth Sci. 64, 42-57.

Donovan, A.D., Djakic, A.W., Ioannides, N.S., Garfield, T.R., Jones, C.R., 1993. Sequence Stratigraphic Control on Middle and Upper Jurassic Reservoir Distribution Within the UK Central North Sea, 4. Geological Society, London, pp. 251-269. Petroleum Geology Conference Series.

Doyle, P., Poiré, D.G., Spalletti, L.A., Pirrie, D., Brenchley, P., Matheos, S.D., 2005. Relative oxygenation of the Tithonian - Valanginian Vaca Muerta-Chachao formations of the Mendoza Shelf, Neuquén Basin, Argentina. In: Veiga, G., Spalletti, L., Howell, J., Schwarz, E. (Eds.), The Neuquén Basin: a Case Study in Sequence Stratigraphy and Basin Dynamics, 252, pp. 185-206. Geol. Soc. Lond., Spec. Publ.

Dumas, S., Arnott, R.W.C., 2006. Origin of hummocky and swaley cross-stratificationthe controlling influence of unidirectional current strength and aggradation rate. Geology 34, 1073-1076.

Edwards, C.M., Howell, J.A., Flint, S.S., 2005. Depositional and stratigraphic architecture of the Santonian Emery Sandstone of the Mancos Shale: implications for late cretaceous evolution of the Western Interior foreland basin of Central Utah, U.S.A. J. Sediment. Res. 75, 280-299.

Eide, C.H., Howell, J.A., Buckley, S.J., 2015. Sedimentology and reservoir properties of tabular and erosive offshore transition deposits in wave-dominated, shallow-marine strata: Book Cliffs, USA. Pet. Geosci. 21, 55-73.

FactPages - Norwegian Petroleum Directorate, 2020. http://factpages.npd.no/factpage s/.

Franzese, J.R., Spalletti, L.A., 2001. Late Triassic-early Jurassic continental extension in southwestern Gondwana: tectonic segmentation and pre-break-up rifting. J. S. Am. Earth Sci. 14, 257-270.

Franzese, J.R., Veiga, G.D., Schwarz, E., Gómez-Pérez, I., 2006. Tectonostratigraphic evolution of a Mesozoic graben border system: the Chachil depocentre, southern Neuquén Basin, Argentina. J. Geol. Soc. 163, 707-721.

Fraser, S.I., Robinson, A.M., Johnson, H.D., Underhill, J.R., Kadolsky, D.G.A., Connell, R., Johannesen, P., Ravnås, R., 2003. Upper Jurassic. In: Evans, D., Graham, C., Armour, A., Bathurst, P. (Eds.), The Millennium Atlas: Petroleum Geology of the Central and Northern North Sea. The Geological Society of London, London, UK, pp. 157-189.

Giambiagi, L., Tunik, M., Barredo, S., Bechis, F., Ghiglione, M., Alvarez, P., Drosina, M., 2009. Cinemática de apertura del sector norte de la cuenca Neuquina. Rev. Asoc. Geol. Argent. 65, 278-292.

Gowland, S., 1996. Facies characteristics and depositional models of highly bioturbated shallow marine siliciclastic strata: an example from the Fulmar Formation (late Jurassic), UK Central Graben. Geol. Soc. Lond., Spec. Publ. 114, 185-214.

Gulisano, C.A., 1981. El Ciclo Cuyano en el norte de Neuquén y sur de Mendoza. Congreso Geológico Argentino 579-592.

Gulisano, C., Gutiérrez Pleimling, A., 1994. The Jurassic of the Neuquén Basin, a Nequén Province-Field Guide. In: Asociación Geológica Argentina, Serie E2, Buenos Aires, Argentina. 
Gulisano, C.A., Gutiérrez Pleimling, A.R., Digregorio, R.E., 1984. Esquema estratigráfico de la secuencia jurásica del oeste de la provincia del Neuquén. Congreso Geológico Argentino 236-259.

Hampson, G.J., 2000. Discontinuity surfaces, clinoforms, and facies architecture in a wave-dominated, shoreface-shelf parasequence. J. Sediment. Res. 70, 325-340.

Hodgson, D., Brooks, H.L., Ortiz-Karpf, A., Spychala, Y., Lee, D.R., Jackson, C.A., 2018 Entrainment and abrasion of megaclasts during submarine landsliding and their impact on flow behaviour. Geol. Soc. Lond., Spec. Publ. 477, 223-240.

Howard, J.D., Reineck, H.-E., 1981. Depositional facies of high energy beach-to-offshore sequence, comparison with low energy sequence. APPG Bull. 65, 807-830.

Howell, J.A., Flint, S.S., 1996. A model for high resolution sequence stratigraphy within extensional basins. Geol. Soc. Lond., Spec. Publ. 104, 129-137.

Howell, J.A., Schwarz, E., Spalletti, L.A., Veiga, G.D., 2005. The Neuquén Basin: an overview. Geol. Soc. Lond., Spec. Publ. 252, 1-14.

Isla, M.F., Coronel, M., Schwarz, E., Veiga, G.D., 2020a. Depositional architecture of a wave-dominated clastic shoreline (Pilmatué Member, Argentina): improving knowledge about the preservation of bar-trough systems. Mar. Pet. Geol. https://doi. org/10.1016/j.marpetgeo.2020.104417.

Isla, M.F., Schwarz, E., Veiga, G.D., 2020b. The record of a non-barred clastic shoreline. Geology 48. https://doi.org/10.1130/G46800.1.

Johnson, H.D., Baldwin, C.T., 1996. Shallow clastic seas. In: Reading, H.R. (Ed.), Sedimentary Environments: Processes, Facies and Stratigraphy, 3rd ed. Blackwell, pp. 232-280.

Legarreta, L., Uliana, M.A., 1991. Jurassic-Marine Oscillations and Geometry of BackArc Basin Fill, Central argentine Andes. In: Macdonald, D.I.M. (Ed.), Sedimentation, Tectonics and Eustasy: Sedimentation, Tectonics and Eustasy: Sea-Level Changes at Active Margins. Blackwell Scientific, pp. 429-450.

Legarreta, L., Uliana, M.A., 1996. The Jurassic succession in west-Central Argentina: stratal patterns, sequences and paleogeographic evolution. Palaeogeogr. Palaeoclimatol. Palaeoecol. 120, 303-330.

Løseth, T.M., Ryseth, A.E., Young, M., 2009. Sedimentology and sequence stratigraphy of the middle Jurassic Tarbert Formation, Oseberg South area (northern North Sea). Basin Res. 21, 597-619.

MacEachern, J.A., Pemberton, S.G., 1992. Ichnological Aspects of cretaceous Shoreface Successions and Shoreface Variability in the Western Interior Seaway of North America. Applications of Ichnology to Petroleum Exploration 57-84.

MacEachern, J.A., Zaitlin, B.A., Pemberton, S.G., 1999. A sharp-based sandstone of the Viking Formation, Joffre Field, Alberta, Canada; criteria for recognition of transgressively incised shoreface complexes. J. Sediment. Res. 69, 876-892.

MacEachern, J.A., Pemberton, S.G., Bann, K.L., Gingras, M.K., 2007. Departures from the Archetypal Ichnofacies: Effective Recognition of Physico-Chemical Stresses in the Rock Record. In: MacEachern, J.A., Bann, K.L., Gingras, M.K., Pemberton, S.G. (Eds.), Applied Ichnology, SEPM Society for Sedimentary Geology, Short Course Notes, vol. 52, pp. 65-93.

Mannie, A.S., Jackson, C.A.-L., Hampson, G.J., 2014. Structural controls on the stratigraphic architecture of net-transgressive shallow-marine strata in a saltinfluenced rift basin: Middle-to-Upper Jurassic Egersund Basin, Norwegian North Sea. Basin Res. 26, 675-700.

Mannie, A.S., Jackson, C.A.-L., Hampson, G.J., Fraser, A.J., 2016. Tectonic controls on the spatial distribution and stratigraphic architecture of a net-transgressive shallowmarine synrift succession in a salt-influenced rift basin: Middle to Upper Jurassic, Norwegian Central North Sea. J. Geol. Soc. 173, 901-915.

Morris, J.E., Hampson, G.J., Johnson, H.D., 2006. A sequence stratigraphic model for an intensely bioturbated shallow-marine sandstone: the Bridport Sand Formation, Wessex Basin, UK. Sedimentology 53, 1229-1263.

Niedoroda, A.W., Swift, D.J.P., Thorne, J.A., 1989. Modeling shelf storm beds: controls of bed thickness and bedding sequence. In: Morton, R.A., Nummedal, D. (Eds.), Shelf sedimentation, Shelf Sequences and Related Hydrocarbon Accumulation. Proceedings of the 17th Annual Research Conference, Gulf Coast Section. Society of Economic Paleontologists and Mineralogists Foundation, pp. 15-39.

Onyenanu, G.I., Jacquemyn, C.E.M.M., Graham, G.H., Hampson, G.J., Fitch, P.J.R., Jackson, M.D., 2018. Geometry, distribution and fill of erosional scours in a heterolithic, distal lower shoreface sandstone reservoir analogue: Grassy Member, Blackhawk Formation, Book Cliffs, Utah, USA. Sedimentology 65, 1731-1760.

Pemberton, S.G., MacEachern, J.A., Dashtgard, S.E., Bann, K.L., Gingras, M.K. Zonneveld, J.-P., 2012. Shorefaces. In: Knaust, D., Bromley, R.G. (Eds.), Trace Fossils as Indicators of Sedimentary Environments. Developments in Sedimentology, 64. Elsevier, pp. 563-603.
Plint, A.G., 2010. Wave- and storm-dominated shoreline and shallow-marine systems. In: James, N.P., Dalrymple, R.W. (Eds.), Facies Models 4. Geological Association of Canada, St. John's, pp. 167-200.

Privat, A., Hodgson, D.M., Jackson, C.A-L., Schwarz, E., Peakall, J., August 2018. Québec City. 20th International Sedimentological Congress, 13-17th, Québec City Canada (oral presentation).

Ravnås, R., Steel, R.J., 1998. Architecture of Marine Rift-Basin Successions. AAPG Bull. $82,110-146$.

Ravnås, R., Bondevik, K., Helland-Hansen, W., Lømo, L., Ryseth, A., Steel, R.J., 1997. Sedimentation history as an indicator of rift initiation and development: the late Bajocian-Bathonian evolution of the Oseberg-Brage area, northern North Sea. Nor. Geol. Tidsskr. 77, 205-232.

Reading, H.G., Collinson, J.D., 1996. Clastic coasts. In: Reading, H.G. (Ed.), Sedimentary Environments: Processes, Facies and Stratigraphy, 3rd ed. Blackwell Science, pp. 154-231.

Reineck, H.-E., 1977. Natural indicators of energy level in recent sediments: the application of ichnology to a coastal engineering problem. In: Crimes, T.P., Harper, J.C. (Eds.), Trace Fossils, 2, pp. 265-272.

Riccardi, A.C., 2008. El Jurásico de la Argentina y sus amonites. Rev. Asoc. Geol. Argent. $63,625-643$.

Sagripanti, L., Folguera, A., Giménez, M., Vera, E.R., Fabiano, J., Molnar, N., Fennell, L., Ramos, V.A., 2014. Geometry of Middle to late Triassic extensional deformation pattern in the Cordillera del Viento (Southern Central Andes): a combined field and geophysical study. J. Iber. Geol. 40, 349-366.

Schwarz, E., Álvarez-Trentini, G., Valenzuela, M.E., 2013. Ciclos mixtos carbonáticos/ silicoclásticos en el Miembro Superior de la Formación Mulichinco (yacimiento Cañadón Amarillo, Cuenca Neuquina central): Implicancias secuenciales y para caracterización de reservorios. Latin American Journal of Sedimentology and Basin Analysis 20, 21-49.

Schwarz, E., Veiga, G.D., Álvarez Trentini, G., Spalletti, L.A., 2016. Climatically versus eustatically controlled, sediment-supply-driven cycles: carbonate-siliciclastic, highfrequency sequences in the valanginian of the Neuquén Basin (Argentina). J. Sediment. Res. 86, 312-335.

Schwarz, E., Veiga, G.D., Álvarez Trentini, G., Isla, M.F., Spalletti, L.A., 2018. Expanding the spectrum of shallow-marine, mixed carbonate-siliciclastic systems: processes, facies distribution and depositional controls of a siliciclastic-dominated example. Sedimentology 65, 1558-1589.

Snedden, J.W., Nummedal, D., 1991. Origin and geometry of storm-deposited sand beds in modern sediments of the Texas Continental Shelf. In: Swift, D.J.P., Oertel, G.F., Tillman, R.W., Thorne, J.A. (Eds.), Shelf Sand and Sandstone Bodies, 14, pp. 283-308. Int. Assoc. Sedimentol. Spec. Publ.

Spalletti, L.A., Parent, H., Veiga, G.D., Schwarz, E., 2012. Amonites y Bioestratigrafía del Grupo Cuyo en la Sierra de Reyes (Cuenca Neuquina central, Argentina) y su significado secuencial. Andean Geol. 39, 464-481.

Taylor, A.M., Goldring, R., 1993. Description and analysis of bioturbation and ichnofabric. J. Geol. Soc. 150, 141-148.

Veiga, G.D., Schwarz, E., Spalletti, L.A., 2011. Análisis estratigráfico de la Formación Lotena (Calloviano superior-Oxfordiano inferior) en la Cuenca Neuquina Central, República Argentina: Integración de información de afloramientos y subsuelo. Andean Geol. 38, 171-197.

Veiga, G.D., Schwarz, E., Spalletti, L.A., Massaferro, J.L., 2013. Anatomy and sequence architecture of the early post-rift in the Neuquén Basin (Argentina): a response to physiography and relative sea-level changes. J. Sediment. Res. 83, 746-765.

Vergani, G.D., Tankard, A.J., Belotti, H.J., Welsink, H.J., 1995. Tectonic evolution and paleogeography of the Neuquén Basin, Argentina. In: Tankard, A.J., Suárez Soruco, R., Welsink, H.J. (Eds.), Petroleum Basins of South America, 62, pp. 383-402. AAPG Memoirs.

Walker, R.G., Plint, A.G., 1992. Wave- and storm-dominated shallow marine systems. In: Walker, R.G., James, N.P. (Eds.), Facies Models: Response to Sea Level Change. Geological Association of Canada, pp. 219-238.

Walsh, J.P., Corbett, D.R., Alexander, C.R., 2018. Source-to-sink sedimentation: insights from modern continental-margin system studies. In: 20th International Sedimentological Congress, 13-17th August 2018, Québec City, Canada (Poster presentation).

Wetzel, A., Uchman, A., 1998. In: Schieber, J., Zimmerle, W., Sethi, P. (Eds.), Biogenic sedimentary structures in mudstones - An overview. Shales and Mudstones, Schweizerbart, pp. 351-369.

Wheatcroft, R.A., 1990. Preservation potential of sedimentary event layers. Geology 18, $843-845$. 